\title{
WHITHER EGYPT? AGAINST RELIGIOUS FASCISM AND LEGAL AUTHORITARIANISM: PURE REVOLUTION, POPULAR COUP, OR A MILITARY COUP D'ÉTAT? ${ }^{1}$
}

\author{
Mohamed A. Arafa ${ }^{2}$ \\ "Those who make peaceful revolution impossible will make violent \\ revolution inevitable."3 \\ -John F. Kennedy \\ "People who succeed have momentum. The more they succeed, the \\ more they want to succeed, and the more they find a way to succeed. \\ Similarly, when someone is failing, the tendency is to get on a downward \\ spiral that can even become a self-fulfilling prophecy." 4 \\ -Anthony Robbins

\section{INTRODUCTION AND OVERVIEW} \\ One important question has been raised since the now-removed \\ Islamist President Mohammad Morsi took the office of the Republic on \\ June 30, 2012: will Egypt be an Islamic State with legislation based on
}

1. The author wants to thank and express his sincere appreciation to the Indiana International and Comparative Law Review (II\&CLR) team for inviting him to share and contribute this Article to this specific project. The author thanks Sukrat Baber, Zachary Ahonen, Nicholas Johnston, and the other staff members for their invaluable comments, suggestions, helpful advice, and their tireless work during the editing process.

2. Assistant Professor of Criminal Law and Criminal Justice at Alexandria University Faculty of Law (Egypt); Adjunct Professor of Law at Indiana University Robert H. McKinney School of Law (USA). Ph.D., Indiana University Robert H. McKinney School of Law (2013); LL.M., University of Connecticut School of Law (2008); LL.B., Alexandria University Faculty of Law (2006). Likewise, Professor Arafa is a Visiting Professor of Business Law at the Arab Academy for Science, Technology, and Maritime Transport ("College of Business Management"). Moreover, Professor Arafa is a Domestic Public Mediator under Alternative Dispute Resolution, Indiana Rule A.D.R. 25 (2012) and served as an Associate Trainee Attorney and Executive Attorney Assistant at Arafa Law Firm (2007). Recently, he has been named to the editorial board of the UNITED STATES-CHINA LAW REVIEW as an "Honored Reviewer." All errors remain the author's. For any comments or questions, please contact the author at marafa@iupui.edu or arafadr_mohamed@yahoo.com.

3. President John F. Kennedy, Address on the First Anniversary for the Alliance for Progress (Mar. 13, 1962), archived at http://perma.cc/GU75-453Y.

4. See generally Anthony Robbins, Unlimited Power: The New Science of Personal Achievement (2003) (explaining the seven successful traits that people who succeed have cultivated in themselves to give them the fire to do whatever it takes to succeed, time and time again). 
Islamic (Sharia) Law? ${ }^{5}$ Egyptian people expel the accusations proliferated by extremist streams and radical Islamists that the concept of a "civil (secular) State" is anti-religious or that it interests only the prosperous minority. ${ }^{6}$ Such untrue discourse and dialogue by extremists misinforms the folks, as the human logic and knowledge shows that a State which is based on just laws, fair statutes, and respect for human rights is not antagonistic to religion, and is in the public interest of the whole community. ${ }^{7}$ Furthermore, playing on religious sentimentalities by saying that God's (Allah's) sovereignty — as argued by some rigid classical religious juristsrather than the people destabilizes the legal institutions and main foundations of the modern democratic civil state by adopting and codifying theocratic and radical notions takes Egypt back into the Dark Ages. ${ }^{8}$ Accordingly, this opens the door to complicated issues in constitutional litigation, and the enactment and repeal of legal rulings according to religious interpretations based on misunderstanding of the principles of divine sovereignty in Islamic law. ${ }^{9}$

5. See generally Mohamed Arafa, President Mursi's Egypt Arab Spring: Does Egypt will Continue to be a Civil State or Under the Umbrella of Islamic (Sharie'a) Law and Islamism?, 9 US-CHINA L. REV. 6 (2012).

6. See id.; see also David D. Kirkpatrick, A Vague Role for Religion in Egyptian Draft $\begin{array}{llll}\text { Constitution, N.Y. } & \text { TIMES, } & \text { Nov. 2012, }\end{array}$ http://www.nytimes.com/2012/11/10/world/middleeast/draft-egyptian-constitution-adopts-arole-for-religion.html?_r=0, archived at http://perma.cc/7YGB-MKBM ("Egypt has settled on a compromise that opens the door to more religion in governance but mainly guarantees that the issue will continue to roil politics, the Parliament and the courts for many years to come. The compromise would insert religion more deeply into the legislative and judicial process by elaborating new guidelines to interpret 'the principles of Islamic law' ...").

7. See Press Release, Coptic Solidarity and Masryoun [Egyptians] Against Religious Discrimination ("MARED"), No to Turning Egypt into a Theocratic Sectarian State (July 27, 2013), archived at http://perma.cc/5BEA-FGHG ("The rights and freedoms of thought and belief. Such discussions prove that the political forces which withdrew from that assembly were right to do so, in view of the hegemony exercised by political Islam and the fact that the assembly did not represent all components of the Egyptian people and its political and social groups.").

8. See Eric Trager, Egypt's Looming Competitive Theocracy, 14 Hudson InstiTuTE Current Trends in Islamist Ideology 27, 36 (Dec. 27, 2012), archived at http://perma.cc/CPF7-HA4C ("No matter which Islamist trend attracts more recruits in the near-term, however, the real competition between them will focus on winning the allegiances of Egypt's next generation. That is to say, the contest among Egypt's theocrats is just getting started."); see also Eric Trager, The Unbreakable Muslim Brotherhood: Grim Prospects for a Liberal Egypt, 90 FOREIGN AFFAIRS 5 (Sept. - Oct., 2011), archived at http://perma.cc/DFA5-YW49 (exploring the recruitment process for the Muslim Brotherhood and its impact on politics); Ella Landau-Tasseron, Leadership and Allegiance in the Society of the Muslim Brothers, Hudson Institute CENTER ON ISLAM, DEMOCRACY, AND THE FUTURE OF THE MUSLIM WORLD (2010), archived at http://perma.cc/F3EL-6LY3.

9. See generally Mariz Tadros, Egypt: The Islamization of State Policy, OpENDEMOCRACY, Jan. 8, 2013, https://www.opendemocracy.net/5050/mariz-tadros/egyptislamization-of-state-policy, archived at http://perma.cc/9VAB-M824. 
Millions of Egyptians took to the streets on June 30, 2013 - the day that led to Morsi's overthrow-to revolt against "religious fascism." ${ }^{10}$ In this regard, Robert Fisk cited that:

For the first time in the history of the world, a coup is not a coup. The army take over, depose and imprison the democratically elected President, suspend the constitution, arrest the usual suspects, close down television stations and mass their armour in the streets of the capital. But the word 'coup' does not - and cannot - cross the lips of the Blessed Barack Obama. Nor does the hopeless UN secretary general Ban Ki-moon dare to utter such an offensive word. It's not as if Obama doesn't know what's going on . . . Is this reticence because millions of Egyptians demanded just such a coup - they didn't call it that, of course - and thus became the first massed people in the world to demand a coup prior to the actual coup taking place? Is it because Obama fears that to acknowledge it's a coup would force the US to impose sanctions on the most important Arab nation at peace with Israel? ${ }^{11}$

Similar to the progression and operation of the Nazi Party and their leader Hitler, the Muslim Brotherhood followed the same track in Egypt under their Islamist leader Morsi. ${ }^{12}$ This fight about converting the Egyptian national identity is a significant global lesson in the separation of

10. See Ahmed Tharwat, Opinion, Why Morsi Fell in Egypt?, StARTribune, July 11, 2013, http://www.startribune.com/opinion/commentaries/214989141.html, archived at http://perma.cc/L82D-3MYV("Cultural fears agitated the secular elite against them. Basic needs brought in the traditional population .... Now the question is what kind of Egypt we are going to have - will it be one big enough to make room for both the liberal secular Westernized crowd and the more traditional religious segments?") (alteration added).

11. See generally Robert Fisk, Comment, When is a Military Coup Not a Military Coup? When it Happens in Egypt-Apparently, THE InDEPENDENT, July 4, 2013, http:/www.independent.co.uk/voices/comment/when-is-a-military-coup-not-a-militarycoup-when-it-happens-in-egypt-apparently-8688000.html, archived at http://perma.cc/TY2Y-7PDF ("Those Western leaders who are telling us Egypt is still on the path to 'democracy' have to remember that Morsi was indeed elected in a real, Westernapproved election.”); see also Wael Nowara, Was Morsi's Ouster a Coup or New Egyptian Revolution?, AL-MONITOR, July 4, 2013, http://www.almonitor.com/pulse/originals/2013/07/was-morsi-ouster-a-coup-or-new-egyptianrevolution.html\#\#ixzz2kyQCvGgn, archived at http://perma.cc/DBK7-YMW3; see also Mohannad Sabry, Egypt's Military Ousts Morsi, Names Judge as Interim President, ALMonitor, July 3, 2013, http://www.al-monitor.com/pulse/originals/2013/07/egyptianmilitary-overthrows-president-mohammed-morsi.html\#ixzz2kyQuVMGR, archived at http://perma.cc/Y6K2-C928.

12. See Tharwat, supra note 10. 
religion and state. ${ }^{13}$ The dismissal of the Muslim Brotherhood's President Morsi cannot be considered a coup d'état because the Egyptian military sided with the will of more than thirty million Egyptians by compelling Morsi to step down, leaving everything to a civilian government, and installing Chief Justice of the Supreme Constitutional Court Adly Mansour to act as an interim President. ${ }^{14}$ Technically and legally speaking, coup means that "the army goes on their own, without any invitation [request] from anyone, taking all the power," leave office because of the army, it cannot be called a coup because it is what the people wanted, and power was placed in a civilian government. ${ }^{16}$

In this domain, the conflation of Islam and Islamism has permeated the interpretation of Egypt's ethnic and personal character, leading one legal and political scholar to label the Muslim Brotherhood as "the Muslims" or "Islamic" while calling their opponents "non-Islamic."17 Islamism is considered a vague politicization of a specific religious attitude throughout the Middle Eastern Arabian World and cannot be associated with Islam as a belief or faith. ${ }^{18}$ By the same token, Egypt strongly resents

13. See Egypt Government Vows to Combat Terrorism, 'Religious Fascism,' ALARABYAI NEws (Aug. 17, 2013), http://english.alarabiya.net/en/News/middleeast/2013/08/17/egypt.html, archived at http://perma.cc/GU2K-CMF3; see also Santi Tarfarella, The Muslim Brotherhood and Religious Fascism, Prometheus UnBound-SANTI TARFARELlA's BLOG ON BOOKS, CUlTURE, AND POlitics (Aug. 17, 2013), http://santitafarella.wordpress.com/2013/08/17/islamic-brotherhood-members-are-religiousfascists/, archived at http://perma.cc/BVJ5-VXDL.

14. See Egypt Government Vows to Combat Terrorism, 'Religious Fascism,' supra note 13; see also Sabry, supra note 11.

15. Interview with Hussein Gohar, head of the foreign affairs committee of the Egyptian Social Democratic Party (Nov. 2013).

16. See Fisk, supra note 11; see also Hüseyin Hayatsever, Morsi's Ouster Not a 'Coup': Egypt's Social Democrat Party, DAILy News, Nov. 15, 2013, http://www.hurriyetdailynews.com/morsis-ouster-not-a-coup-egypts-social-democratparty.aspx?pageID=238\&nID $=57937 \&$ NewsCatID=352, archived at http://perma.cc/4MZSG6D.

17. See Umar Farooq, Egypt's Top Religious Authority: It's Not Anti-Islam to be AntiMorsi, The Christian Science Monitor (June 23, 2013), http://www.csmonitor.com/World/Middle-East/2013/0624/Egypt-s-top-religious-authorityIt-s-not-anti-Islam-to-be-anti-Morsi, archived at http://perma.cc/8Q55-7QP6 ("Egypt's leading Sunni institution disagreed saying 'peaceful opposition to the government is acceptable in Islam.' . . . “As the Egyptian opposition's demands for the resignation of President Mohamed Morsi and fresh elections gain momentum, the beleaguered president's supporters are slamming the opposition as secular and hostile to Islam.") (alterations added).

18. Id. So far, the majority of Egyptians who opposed Morsi's régime were Muslim, and most Egyptian folks in the first round of the presidential elections voted for non-Islamist candidates. See Sherif Mansour, Special Report, On the Divide: Press Freedom at Risk in Egypt, Cомmittee to Protect Journalists (Aug. 14, 2013), http://cpj.org/reports/2013/08/on-divide-egypt-press-freedom-morsi.php, archived at http://perma.cc/9F2Q-2WEB.

Egyptian authorities have also attempted sending imams (moderate religious leaders) to 
some Western mass-media coverage that overlooks violence and terror attacks committed by Islamist organizations in the form of intimidation and terrorizing citizens. ${ }^{19}$ The Egyptian Government, along with Egyptians, are in favor of having a place in a civil democratic Egypt for quiet, peaceful Islamists who would not want to change the State's national character and the form of its government into an Islamic religious theocracy. ${ }^{20}$ The scuffle to define and explain the concept of "Islam" in Egypt has a long legal and constitutional history as those who favor political Islam square off against those who prefer a more secular-oriented form of government. ${ }^{21}$ Generally speaking, the state's main obligation in any country is to preserve public order and protect and defend its national citizens. This duty is generally difficult to harmonize with the accountability of any non-state dynamic. ${ }^{22}$ Historically, the Muslim Brotherhood has incorporated diverse tendencies: from the deeply conservative [traditional and classical]—which have stunned other divisions of Egypt's Muslim society - all the way to neo-religious totalitarianism [particularly under Morsi's leadership]; this incorporation of diverse tendencies has resulted in deep sectarianism and an oppressive style of Islamism among the classes of Egypt. ${ }^{23}$

mosques to deliver sermons in support of the government and to "correct the fallacies of extremist thought," in an attempt to promote a true "Egyptian Islam." See Stephanie McCrummen, In Egypt, A Campaign to Promote an 'Egyptian Islam,' The Washington Post, Oct. 9, 2013, http://articles.washingtonpost.com/2013-1009/world/42862552_1_mohamed-morsi-security-forces-muslim-brotherhood, archived at http://perma.cc/W53T-FTZ2.

19. See generally Matt Bradley, Egypt Rebukes Foreign Press for 'Biased' Coverage, WALL ST. J., Aug. 2013, http://online.wsj.com/article/SB10001424127887323639704579019112899519956.html, archived at http://perma.cc/JW92-HPF6 ("The SIS also castigated the foreign press for not paying enough attention to attacks on Christians and Islamists' 'intimidation' of ordinary Egyptian citizens.").

20. See Abdullah Al-Arian, What Next for the Muslim Brotherhood?, CAIRo REviEW of GlobAL AfFAIRS (Sept. 16, 2013), http://www.aucegypt.edu/GAPP/CairoReview/Pages/articleDetails.aspx?aid=427, archived at http://perma.cc/3P7G-MH77; see also Mark Landler \& Peter Baker, His Options Few, Obama Rebukes Egypt's Leaders, N.Y. Times, Aug. 15, 2013, http://www.nytimes.com/2013/08/16/world/middleeast/obama-statement-on-egypt.html?hp, archived at $\mathrm{http}: / /$ perma.cc/QNK8-NHU6.

21. See McCrummen, supra note 18.

22. McCrummen, supra note 18; see also M. Cherif BAssiouni, The Fight For Democracy in Egypt's Liberation Square: Background Paper 1 (Feb. 10, 2011), archived at http://perma.cc/G9J9-SDU4.

23. See BASSIOUNI, supra note 22, at 7; see also Mohamed Arafa, Towards a Culture for Accountability: A New Dawn for Egypt, 5 PHOENIX L. ReV. 1, 7-8 (2011)

("About eighty to ninety percent of the population is Muslim, while the remainder is Christian. Historically, the Christians have enjoyed freedom of religion, yet they have not always received full equality. In fact, Coptic Christians feel particularly besieged and discriminated against. This identification with nationality first supports the belief that ideological religious radicalism is not likely to take over in the near future."). 
There is political turmoil, violence, and chaos in Egypt, and it must be taken extremely seriously because war on terror under a religious cover, or the umbrella of defending religion or Islam, may permit the state to denyto some extent - the individual's public rights and freedoms. ${ }^{24}$ Further, the futile counter-terrorism policies and strategies only serve to reinforce a chronicle of grievance that supports terrorist recruiting. ${ }^{25}$ Nonetheless, Egypt remains multifaceted: most "liberals" appear to believe that the alqwaat al-moselah(h) al-masriyyah(h) (Egyptian Army) is a "revolutionary savior," while Islamists acknowledge Morsi as the entire and mutual sign of freedom, justice, and confrontation, and as a sound ideal of democratic leadership; neither are truly in touch with reality. ${ }^{26}$ This is why the picture in Egypt is astoundingly contradictory and puzzling. It is obvious that not only do Egyptians see this as a regime-change, but so do other countries' governments. $^{27}$

To further illustrate the far-reaching effects of the June 30 and July 3 events, this Article contains four parts including the introduction. Part two provides a concise framework establishing the theoretical and ethical underpinnings of Egyptian politics. Then, part three discusses the definition of the relevant religious laws and legislation in Egypt and how they can be enacted under Islamic law in the light of the flexible Sharia's definition and interpretation, especially within the new provisions of the 2014 Constitution. This Article concludes in part four by arguing that talks about Islam, Islamism, and political Islam are understood only as discourse about

24. See Egypt Brotherhood Rejects 'Terrorism' Charge: Senior Muslim Brotherhood Official Currently in Hiding Says Coup Leaders' Hands Are 'Drowned in Blood,' ALJAZEERA (Aug. 28, 2013), http://www.aljazeera.com/news/middleeast/2013/08/20138285655559615.html, archived at http://perma.cc/8JPY-3P2L.

25. See generally Khaled Abou El-Fadl, Islam is Now Living Through its Dark Ages: And Rebirth is Not Assured, ABC RELIGION AND ETHICs (June 17, 2013), http://www.abc.net.au/religion/articles/2013/06/17/3783568.htm, archived at http://perma.cc/3J89-YQ8G.

26. See generally Khaled Abou El-Fadl, Did the Military Really Save Egypt?, ABC RELIGION AND ETHICS (July http://www.abc.net.au/religion/articles/2013/07/05/3797287.htm, archived at http://perma.cc/Y9GZ-FV49 ("The military once again has overthrown the first freely elected president after only one year in power. The military claims that it had to act because the protestors in Tahrir Square represented the sovereign will of the people, but this is the same military that has insisted on passing laws shielding it from any civilian oversight or accountability."); see also Tariq Ramadan, The End of Political Islam or the Birth of IslamoCapitalism?, ABC RELIGION AND ETHICS (June 18, 2013), http://www.abc.net.au/religion/articles/2013/06/18/3784422.htm, archived at http://perma.cc/TYM4-UJG6.

27. See Fraid Zahran, What Happened on 30 June? DAILY News, July 17, 2013, http://www.dailynewsegypt.com/2013/07/17/what-happened-in-30-june/, archived at http://perma.cc/6L6R-UWV4. 
power, and always will impede any régime [tyrannical and autonomous] that does not generate a place for its survival. What Egypt essentially needs at the present status quo-more than anything else-is an Islamic resurgence and religious revival in the light of an innovative reinterpretation of Islam [Islamic law] and its teachings as a dialogue of freedom and liberty. Whatever the ultimate aftermath is in Egypt, it will cause undulations that will resonate throughout the Middle East and the rest of the world.

\section{JunE 30 AND July 3 EVENTS: PuRE REVOLUTION, COUNTER- REVOlUTION, “DEMOCRATIC” MilitARY COUP OR "POPULAR” COUP? BACKGROUND AND WHAT BEYOND?}

The massive demonstrations against the first democratically-elected President, Morsi, on June 30, 2013, ${ }^{28}$ marked the one-year anniversary of his inauguration as Egypt's first civilian President. ${ }^{29}$ The Egyptian military claimed that millions of demonstrators across Egypt took to the streets again, in a similar fashion to the January 25,2011 , revolution which toppled former President Hosni Mubarak. ${ }^{30}$ This time their goal was the instantaneous resignation of the Islamist President. ${ }^{31}$ The fundamental

28. Alex Jones, Muslim Brotherhood Wins Election in Egypt: Mohammed Morsi Will be Egypt's Next President; Says Egypt's Capital 'Shall be in Jerusalem, Allah Willing,' SREAVES32 (June 25, 2012), http://sreaves32.wordpress.com/2012/06/24/muslimbrotherhood-wins-election-in-egypt-mohammed-morsi-will-be-egypts-next-president-saysegypts-capital-shall-be-jerusalem-allah-willing/ ("The Muslim Brotherhood's Mohammad Morsi has officially won Egypt's presidential election and will be the country's next president ....") (alteration added).

29. See generally Patrick Kingsley, Protesters Across Egypt Call for Mohamed Morsi to Go, THE GUARDIAN (June 30, 2013), http://www.theguardian.com/world/2013/jun/30/mohamed-morsi-egypt-protests, archived at http://perma.cc/Y6NV-4GQJ.

30. Id.; see also Jones, supra note 28.

31. Kingsley, supra note 29; Shaimaa Fayed \&Yasmine Saleh, Millions Flood Egypt's Streets to Demand Mursi Quit, Reuters, June 30, 2013, http://www.reuters.com/article/2013/06/30/us-egypt-protests-idUSBRE95Q0NO20130630, archived at http://perma.cc/GHR6-B3LJ ("Millions of Egyptians flooded into the streets on the first anniversary of Islamist President Mohamed Mursi's inauguration . . . to demand that he resign in the biggest challenge so far to rule by his Muslim Brotherhood. Waving national flags and chanting 'Get out!' . . . . Many demonstrators bellowed their anger at the Brotherhood, which they accuse of hijacking Egypt's revolution and using electoral victories to monopolize power and impose Islamic law.") (alterations added); see also Hamza Hendawi \& Alastair Macdonald, Egypt Protests: Thousands Gather at Tahrir Square to Demand Morsi's Ouster, THE STAR (June 30, 2013), http://www.thestar.com/news/world/2013/06/30/egypt_protests_thousands_gather_at_tahrir_ square_to_demand_morsis_ouster.html, archived at $\overline{\mathrm{http}} / / / \mathrm{perma}$.cc/GCB8-E4EW ("Thousands of opponents and supporters of Egypt's Islamist president began massing in . . . competing rallies ... gearing up for a day of massive nationwide protests that many fear 
concerns for demanding Morsi's stepping-down comprised allegations that he was gradually pushing through a totalitarian, Islamist program without regard to liberal adversaries or the rule of law. ${ }^{32}$ Further, the mass protests were against the notorious dictatorial Constitutional Declaration issued by Morsi. ${ }^{33} \mathrm{He}$ professed his executive decisions were immune from judicial review, giving himself comprehensive legislative influences until a new constitution endorsed his powers as inalienable, and placed himself above the law. ${ }^{34}$ These actions caused political opponents to discuss ways of his removal and to call for earlier presidential elections. ${ }^{35}$

On April 28, 2013, Tamarod (Repeal Campaign) was underway as a popular grassroots movement-supported by various political movements and parties - to gather signatures to remove the Islamist President by June $30 .^{36}$ The movement called for nonviolent protests and peaceful marches across Egypt, particularly in front of the Presidential Palace in Cairo. ${ }^{37}$ Meanwhile, pro-Morsi groups calling for support of the President and his constitutional and legal legitimacy started demonstrations at multiple places and numerous districts. ${ }^{38}$ Several distinguished extremists and radical Islamic public figures threatened Egypt's national secular and liberal-

could turn deadly.") (alterations added); Arafa, supra note 23, at 2-3.

32. See Kingsley, supra note 29.

33. Kingsley, supra note 29; Jones, supra note 28.

34. See Abdel-Rahman Hussein, Mohamed Morsi Indicates Judicial Decree Will Be Limited, THE GuARDIAN (Nov. 26, 2012), http://www.theguardian.com/world/2012/nov/26/mohamed-morsi-decree-sovereign-matters, archived at http://perma.cc/7QGF-XTX2 ("Egypt's President tries to defuse 'immunity' decree crisis by indicating acceptance of judiciary-proposed compromise . . . .Egypt's President has agreed that only his decisions related to 'sovereign matters' would be protected from judicial review .....") (alterations added).

35. Charles Levinson \& Matt Bradley, In Egypt, the 'Deep State' Rises Again: Meetings Between Generals and Opposition Show the Workings of an Assortment of Forces that Wield Tremendous Influence, WALL ST. J., Jul. 19, 2013, http://online.wsj.com/news/articles/SB10001424127887324425204578601700051224658, archived at http://perma.cc/M6H8-6NEN ("In the months before the military ousted President Mohammed Morsi, Egypt's top generals met regularly with senior aides to opposition leaders .... If the opposition could put enough protesters in the streets, the military would step in-and forcibly remove the president.") (alteration added); see also Nada Hussein Rashwan, Egypt's 'Rebel' Campaign Gathered 22 mn Signatures, Says Spokesman, AHRAMONLINE (June 29, 2013), http://english.ahram.org.eg/NewsContent/1/64/75244/Egypt/Politics-/Egypts-Rebelcampaign-gathered--mn-signatures,-say.aspx, archived at http://perma.cc/3MQ7-GAP9.

36. See Kingsley, supra note 29.

37. See Rashwan, supra note 35; Mahitab Assran, Reactions Vary to Tamarod's 30 June Plans, DAILY News, June 5, 2013, http://www.dailynewsegypt.com/2013/06/05/reactionsvary-to-tamarods-30-june-plans/, archived at http://perma.cc/ABC3-GFVL; see also Egypt Warms up for a Decisive Day of Anti-and Pro-Morsi Protests, AHRAMONLINE (July 2, 2013), http://english.ahram.org.eg/NewsContent/1/64/75483/Egypt/Politics-/Egypt-warms-up-for-adecisive-day-of-anti-and-proM.aspx, archived at http://perma.cc/RP9G-BFZE.

38. See Jones, supra note 28. 
conservative citizens and the Coptic Christians not to join the protests, otherwise their "businesses, cars, homes, schools, and churches" might "catch fire.",39

Morsi's removal from office by the military was a result of the Egyptians' free will, not a military coup d'état. ${ }^{40}$ While Egypt's infrastructure was in poor condition before Morsi came to power, many of these problems were attributed to Morsi and his frail government. ${ }^{41}$ Persistent media coverage demonized and criticized the Morsi administration. $^{42}$ The Muslim Brotherhood has been criticized for using Presidential power in the constitutional committee to pass a zealously dubious Islamist 2012 Constitution. ${ }^{43}$ As a result, secular and liberal political parties, along with church representatives, withdrew from the constituent assembly. ${ }^{44}$ This resulted in an upsurge in the price of food staples, gasoline, main commodities, taxes, and fundamental public services. $^{45}$ Further, the purchasing power of the pound plummeted

39. Raymond Ibrahim, Pro-Morsi Forces Threaten Christians Against Protesting, HUMAN EvENTS (July 3, 2013), http://www.humanevents.com/2013/07/03/pro-morsiterrorists-threaten-christians-against-protesting/, archived at http://perma.cc/8RN7-GSHD; see Al Arabiya, Tahrir Square Protesters Show President Mursi the 'Red Card', ALARABIYA NEWS (June 30, 2013), http:/english.alarabiya.net/en/News/middleeast/2013/06/30/Egypt-braces-for-June-30-rebellion-as-Mursi-marks-first-year-.html, archived at http://perma.cc/DZX6-6647.

40. See Rashwan, supra note 35.

41. Alain Gresh, Don't Exclude the Muslim Brotherhood: Shadow of the Army Over Egypt's Revolution, LE Monde DiplomatiQue, July 29, 2013, http://mondediplo.com/2012/08/02egypt, archived at http://perma.cc/WTB9-YHSP ("The Muslim Brotherhood proved vulnerable in power both to its old secretive culture and a new popular awareness of its inaptitude for government. But it has to be included in any pluralist attempt to restore democracy.").

42. See Levinson \& Bradley, supra note 35.

43. See Kingsley, supra note 29.

44. See Ibrahim Al-Masry, Non-Islamist Members Withdraw From Constitutional Assembly, DAILY NEws, Nov. 24, 2012, http://www.dailynewsegypt.com/2012/11/24/allcivilian-parties-withdraw-from-constitutional-assembly/, archived at http://perma.cc/8DUQJ7DH ("The crisis within the Constituent Assembly has escalated with the withdrawal of all non-Islamist representatives. The withdrawal comes as a reaction to the constitutional declaration issued by President Mohamed Morsy . . . making his decrees above judicial review.") (alteration added); see also Egyptian Churches Withdraw From Constituent Assembly, EGYPT INDEPENDENT (Nov. 2012), http://www.egyptindependent.com/news/egyptian-churches-withdraw-constituent-assembly, archived at $\mathrm{http}: / /$ perma.cc/4PVD-BFAX.

45. Heba Saleh, Egypt's Power Crisis Worsened by Declining Natural Gas Production, FINANCIAL TIMES (May 29, 2013), http://www.ft.com/cms/s/0/82ae9418-c857-11e2-8cb700144feab7de.html\#axzz2sUA362ib, archived at http://perma.cc/EEL7-27WC; see also Diesel Fuel Crisis Adds to Egypt's Cocktail of Political, Economic Woes, Fox News (Mar. 11, 2013), http://www.foxnews.com/world/2013/03/11/diesel-fuel-crisis-adds-to-egyptcocktail-political-economic-woes/, archived at http://perma.cc/C5FQ-A7SE ("For several months, Egyptians have been hit by shortages of diesel, the main fuel that truckers, bus 
compared to other foreign currencies, which resulted in a large portion of the population falling below the poverty line. ${ }^{46}$ Public security continued to deteriorate as street gangs, criminal thugs, and thieves became more prevalent, and the country's economic productivity spiraled downward. ${ }^{47}$ Tourism, which has long been one of Egypt's largest sources of national income, plunged to an estimated 25 to 35 percent of what it was under Mubarak. ${ }^{48}$ Diplomatic difficulties developed during construction of the Ethiopian al-nehedaa $(h)$ [renaissance] Dam along the Nile River, affecting Egypt's share of water, and downgrading formerly solid diplomatic links with main allies in the West and Middle East. ${ }^{49}$

On June 30, millions of demonstrators protested across Egypt both in favor and against Morsi. ${ }^{50}$ The Egyptian military argued that the number was more than ten million, and reportedly one of the biggest mass protests in world revolutionary history. ${ }^{51}$ That was followed by the Egyptian Army

drivers, farmers, bakers and a range of industries rely on to keep their engines running. The diesel crisis is now. . . adding to the country's economic problems.") (alteration added); see also David D. Kirkpatrick, Short of Money, Egypt Sees Crisis on Fuel and Food, N.Y. TIMES, Mar. 30, 2013, http://www.nytimes.com/2013/03/31/world/middleeast/egypt-shortof-money-sees-crisis-on-food-and-gas.html?pagewanted=all, archived at http://perma.cc/UYM2-E84U.

46. Saleh, supra note 45.

47. See 16 Egyptian Soldiers Killed at Israel Border, Ahramonline (Aug. 5, 2012), http://english.ahram.org.eg/NewsContent/1/64/49660/Egypt/Politics-/UPDATE---Egyptiansoldiers-killed-at-the-Israel-bo.aspx, archived at http://perma.cc/JXF6-87SZ ("Egypt President Mohamed Morsi says 'perpetrators will be punished;' Palestinian Hamas condemns blast while unconfirmed reports suggest 'Islamists' orchestrated the episode.”).

48. Patrick Kingsley, Egypt's Mohamed Morsi Appoints Hardline Islamist to Govern Luxor, THE GUARDIAN (June 17, 2013), http://www.theguardian.com/world/2013/jun/17/morsi-appoints-islamist-governor-luxor, archived at $\mathrm{http}: / /$ perma.cc/DY6H-DM88.

49. Charles Kennedy, Ethiopia Ignores Egypt's Empty Threats and Continues with Construction of Dam, OIL PRICE (July 4, 2013), http://oilprice.com/Latest-EnergyNews/World-News/Ethiopia-Ignores-Egypts-Empty-Threats-and-Continues-with-

Construction-of-Dam.html, archived at http://perma.cc/5NUF-STGK ("Despite the stiff opposition from Egypt, Ethiopia is ploughing ahead with the construction of the Grand Ethiopian Renaissance Dam, a $\$ 4.2$ billion hydroelectric dam that is located on the river Nile, and when completed will be Africa's largest, with a generating capacity of $6,000 \mathrm{MW}$. ... Egypt are $[$ sic $]$ worried that damming the Nile could reduce the flow of water that passes through their country, but there could also be another reason for their opposition; bitterness.") (alterations added).

50. See Rashwan, supra note 35 .

51. On July 1, 2013, millions of demonstrators against Morsi gathered in Tahrir Square and outside the presidential palace, and security forces and police officers wearing their uniforms joined the anti-Morsi protests and recited: "The police and the people are one." Abby Ohlheiser, What Sunday's Massive Anti-Morsi Protests in Egypt Looked Like, THE WiRE/GLOBAL (June 30, 2013, 8:41 PM), http:/www.thewire.com/global/2013/06/hereswhat-todays-massive-anti-morsi-protests-egypt-looked/66728/, archived at http://perma.cc/M2RJ-ULX7 ("Crowd estimates are always approximate, but Egyptian military representatives are estimating as many as 14 million demonstrators took to the 
issuing a forty-eight hour deadline [last word ultimatum] that gave the country's politicians until July 3 to meet the Egyptian people's demands, and if the deadline was not met, the Army threatened to intervene and to announce a new political roadmap for Egypt. ${ }^{52}$ After the military warning, clashes between pro and anti-Morsi forces took place and the presidency rejected the Egyptian Armed Forces' forty-eight hour ultimatum, promising that Morsi would pursue his plans for national dialogue and reconciliation to solve the political crisis. ${ }^{53}$

Late in the night of July 2, Morsi, in his final speech on State National Television, declared that he would "defend the legitimacy of his elected office with his life" and added that "there is no substitute for legitimacy" as he vowed not to resign. ${ }^{54}$ As these presumed negotiations failed and the deadline for the army's ultimatum approached on July 3, the military intervened. $^{55}$ The Army removed Morsi from power and installed the President of the Supreme Constitutional Court, Chief Justice Adly Mansour to act as an "Interim President." Upon installation, the Army charged Mansour with launching a transitional technocratic government while also suspending the questionable 2012 Constitution. ${ }^{57}$ Morsi condemned his

streets today, out of a total population of 84 million. The consensus is that country-wide, the numbers of demonstrators are in the millions.").

52. Alastair Beach \& Heather Saul, Egypt on the Edge: Troops Seen Preparing for Unarmed Combat after President Morsi Rebuffs Army 48-hour Coup Deadline, THE INDEPENDENT (July 1, 2013), http://www.independent.co.uk/news/world/africa/egypt-on-theedge-troops-seen-preparing-for-unarmed-combat-after-president-morsi-rebuffs-army48hour-coup-deadline-8681882.html, archived at http://perma.cc/JDT3-UEYW ("Egypt set for a military coup if Muslim Brotherhood President clings to power . . Egyptian troops have been seen gearing up for unarmed combat as the clocked continued to tick on the 48hour ultimatum handed to President Mohamed Morsi.").

53. See Egypt President Morsi Warns of Army Ultimatum 'Confusion', BBC News (July 2, 2013, 5:30 ET), http://www.bbc.co.uk/news/world-middle-east-23140212, archived at http://perma.cc/NK3G-9QXG.

54. See Egypt's Morsi Says He Will Not Step Down: President Insists He is the “Guardian of Legitimacy" as Deadline from Army Looms, AL-JAZEERA, (July 2, 2013, 10:27 PM), http://www.aljazeera.com/news/middleeast/2013/07/20137222343142718.html, archived at http://perma.cc/T4JP-YET9 ("The Egyptian President, Mohamed Morsi, has said he will not step down as demanded by millions of protesters, vowing to protect his 'constitutional legitimacy' with his life ... . [he] accused loyalists of his predecessor Hosni Mubarak of riding the current wave of protests to topple his regime.") (alteration added).

55. See id.

56. See Sayed Gamal El-Din, Egypt's New Interim President: Judge Adly Mansour,

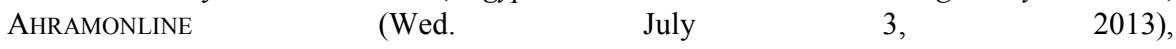
http://english.ahram.org.eg/NewsContentPrint/1/0/75638/Egypt/0/Egypts-new-interimpresident-Judge-Adly-Mansour.aspx, archived at http://perma.cc/U8KQ-35V6.

57. See Egypt Military Unveils Transitional Roadmap: Military Commander-in-Chief Abdel-Fattah El-Sisi Dismisses Egypt's President Amid Massive Opposition Protests, Unveils Roadmap for Country's Political Future, AHRAMOnLine (July 3, 2013), http://english.ahram.org.eg/NewsContentPrint/1/0/75631/Egypt/0/Egypt-military-unveilstransitional-roadmap.aspx, archived at http://perma.cc/HKL6-P8ZC

("Egypt's military commander-in-chief General Abdel-Fattah El-Sisi unveiled 
overthrow as a "complete military coup" by former General el-Sisi and urged everyone to "adhere to peacefulness and avoid shedding blood ... .58 Morsi's assistant added that Morsi's removal was "a military coup" and that "there is no democracy without the ballot box . . .." Morsi has

a 'roadmap' for Egypt's political future proposed by the opposition, which included the ouster of President Mohamed Morsi to make way for snap presidential elections. The roadmap will include the following points:

-The temporary suspension of the current constitution.

-Empowering the head of Egypt's High Constitutional Court ("HCC") to run the country until a new president is elected via early presidential polls.

-Forming a new technocratic government and asking the HCC to hasten the passing of a parliamentary elections law, currently being reviewed by the $\mathrm{HCC}$, to allow for parliamentary elections.

-Forming a committee to amend controversial articles of the temporarily suspended constitution.

-Laying down a media code of ethics to guarantee the media's professionalism.

-Forming a committee to foster 'national reconciliation.'

-Taking immediate steps to include youth in decision making circles.

In his televised statement, [the strongest Defense Minister, General] El-Sisi stressed that the armed forces had no intention to enter political life, but said it would 'never turn a blind eye to the aspirations of the Egyptian people.'”).

In this regard, Morsi was put under house arrest, and was believed to be at a safe undisclosed military base and his travel was restricted and standing for criminal investigations and trial. See Matt Bradley \& Reem Abdellatif, Egyptian Military Ousts President Morsi: Morsi Rejects Decision; Constitution Is Suspended, WALL St. J., July 4, 2013, http://online.wsj.com/news/articles/SB10001424127887323899704578583191518313964,

archived at http://perma.cc/YC53-KGC5 ("The leader of Egypt's military ousted President Mohammed Morsi from office and replaced him with the head of the country's constitutional court - a move the presidential palace quickly branded a "complete military coup."'); see also David D. Kirkpatrick, Army Ousts Egypt's President; Morsi Is Taken Into Military Custody, N.Y. TIMES, July 2013, http://www.nytimes.com/2013/07/04/world/middleeast/egypt.html?pagewanted=all\&_r=0, archived at http://perma.cc/R6KH-Y5MZ ("Egypt's military officers removed the country's first democratically elected president, Mohamed Morsi . . . suspended the Constitution and installed an interim government presided over by a senior jurist.") (alteration added).

58. Egypt's Army Ousts Morsi, Who Calls it a "Coup," CBSNews (July 3, 2013), http://www.cbsnews.com/news/egypts-army-ousts-morsi-who-calls-it-a-coup/, archived at http://perma.cc/QF3Y-LKYP (alteration added).

59. Dan Murphy, Egypt's Muslim Brotherhood and Morsi Have their Backs to the Wall, THE Christian SCIENCE Monitor (July 3, 2013), http://www.csmonitor.com/World/Security-Watch/Backchannels/2013/0703/Egypt-s-

Muslim-Brotherhood-and-Morsi-have-their-backs-to-the-wall, archived at http://perma.cc/5PHP-E6EC (alteration added). The declaration of the Islamist President's removal was met with cheers in Tahrir ("Liberation") Square and demonstrators shouted "Long Live Egypt" and launched fireworks. See Carlo Davis, Egypt Celebrations, Protests Mark Removal of President Mohamed Morsi By Army, The Huffington Post (July 3, 2013, 4:51 PM), http://www.huffingtonpost.com/2013/07/03/egypt-celebrates-protests-removal-ofmorsi_n_3542771.html?view=print\&comm_ref=false, archived at http://perma.cc/B2YJ8JSP ("Opposition demonstrators gathered in Tahrir Square and outside the Presidential Palace in Cairo to celebrate the Army's move, setting off fireworks and waving scores of 
remained in detention since July 3, 2013, and he and fourteen other top Muslim Brotherhood leaders (including the Supreme Guide Mohammad Badi'ee and leading member Khairat el-Shater) were arrested and are standing trial for criminal charges of inciting murder against protestors during a December 4, 2012 protest of the ithaddiyaah( $h$ ) Presidential Palace. ${ }^{60}$ Additionally, the Cairo Court for Urgent Matters-first-level trial court - debarred "activities of the Muslim Brotherhood organization and its non-governmental organization and all the activities that it participates in and any organization derived from it." 61 The ban also covers any activities the Muslim Brotherhood financed or supported in any way, and orders the seizure and freeze of the group's assets.

Egyptian flags.”); Dan Murphy, Egypt's Muslim Brotherhood and Morsi Have Their Backs to the Wall, THE Christian SCIENCE MONitor (July 3, 2013), http://www.csmonitor.com/World/Security-Watch/Backchannels/2013/0703/Egypt-s-

Muslim-Brotherhood-and-Morsi-have-their-backs-to-the-wall, archived at http://perma.cc/9P4Z-V3QQ ("Warnings of a coup and the death of democracy come from senior Muslim Brotherhood members and advisers of Egyptian President Mohamed Morsi . . ..") (alteration added); "[O]fficials around Morsi and the Brotherhood appear to be gambling that they can face down the military with their own street power and by appealing to the democratic victory of an election held about a year ago. They keep referring to a military coup and hinting at the possibility of horrible bloodshed if events continue to unfold as they are. But any hopes that foreign powers like the US will line up to support them in response to this framing are fading fast." (alteration added) $I d$.

60. Kareem Fahim, Morsi and Muslim Brotherhood Leaders Charged With Inciting Murder, N.Y. TIMES (Sept. 1, 2013), http://www.nytimes.com/2013/09/02/world/middleeast/morsi-and-muslim-brotherhoodleaders-charged-with-inciting-murder.html, archived at http://perma.cc/PB8F-HGY9 ("Egypt's chief prosecutor ordered former President Mohamed Morsi and other Muslim Brotherhood leaders . . . to stand trial on charges including inciting murder . . . [ [H]e awaits a second trial on charges of complicity in the deaths of hundreds of protesters.") (alterations added); see Egypt Shuts Down Four TV Stations, BBC NEws (Sept. 3, 2013, 7:53 ET), http://www.bbc.co.uk/news/world-middle-east-23941208, archived at http://perma.cc/76HW-N4X2 ("An Egyptian court has ordered the closure of four television channels that have been accused of sympathizing with the Muslim Brotherhood. They include the Brotherhood's own station, Ahrar 25, and the Egyptian arm of Al-Jazeera.").

61. See Richard Spencer, Egypt's Army Drives Mohammed Morsi from Presidency and Power in Dramatic Coup, InDEPENDENT (July 4, 2013), http://www.independent.ie/worldnews/middle-east/egypts-army-drives-mohammed-morsi-from-presidency-and-power-indramatic-coup-29394490.html, archived at http://perma.cc/JWU6-2F9Z.

62. Michael Georgy \& Mike Collett-White, Egypt Court Bans All Muslim Brotherhood Activities, REUTERS (Sept. 23, 2013), http://www.reuters.com/article/2013/09/23/usegyptbrotherhood-urgent-idUSBRE98M0HL20130923, archived at http://perma.cc/KGH3-8SHA ("An Egyptian court . . . banned the Muslim Brotherhood from carrying out any activities in the country and ordered the seizure of the group's funds, widening a campaign to debilitate the Islamist movement of deposed President Mohamed Mursi") (alteration added); David D. Kirkpatrick, Egyptian Court Shuts Down the Muslim Brotherhood and Seizes Its Assets, N.Y. TIMES, Sept. 23, 2013, http://www.nytimes.com/2013/09/24/world/middleeast/egyptiancourt-bans-muslim-brotherhood.html, archived at http://perma.cc/Z38N-ZHMU ("An Egyptian court ... issued an injunction dissolving the Muslim Brotherhood and confiscating its assets, escalating a broad crackdown on the group less than three months since the 


\section{FOREIGN POLICY REACTIONS AND ARGUMENTS: COUP OR NOT A COUP?}

Foreign perceptions of the Morsi ouster have been conflicting. For instance, in the United States, the media have called attention to President Obama's failure to call the ouster a coup. ${ }^{63}$ If Obama admits that a coup had taken place, then US federal law requires him to cut off military and economic assistance to Egypt; under federal law, all US humanitarian aid must cease to "the government of any country whose duly elected head of government is deposed by military coup d'état or decree or . . a coup d'état or decree in which the military plays a decisive role." 64 In the same vein, the United States cautioned the Egyptian military against a coup by threatening to suspend military support while simultaneously motivating ex-President Morsi to hold early elections. ${ }^{65}$ The Army made it obvious that they were dispassionate in taking over political power, only wanting to make sure that Egypt and its people remain stable and safe and that those involved in the political arena find an agreed political solution which satisfies the needs and wishes of the Egyptians. ${ }^{66}$

It has been argued by the top generals in the Egyptian military that their actions in July did not constitute a coup because the military would not take on an enduring role in Egyptian politics. ${ }^{67}$ Legally speaking, it is

military ousted its ally, President Mohamed Morsi.") (alteration added).

63. Zeke J. Miller, Apparent Egyptian Military Coup Puts Obama in Bind on Aid, Time SwAMPLAND (July 3, 2013), http://swampland.time.com/2013/07/03/apparent-egyptianmilitary-coup-puts-obama-in-bind-on-military-aid/, archived at http://perma.cc/R5V7XTCA ("The military ouster of Egyptian President Mohamed Morsi . . . places the Obama Administration in a difficult situation: if President Obama accepts that a coup has taken place, U.S. law will force him to cut off American military and economic aid to one of America's closest Middle East allies.") (alteration added). The United States funds $20 \%$ of Egypt's military costs (US $\$ 1.3$ billion) and gives another US $\$ 250$ million in economic support. Id.

64. See Consolidated Appropriations Act of 2012, Pub. L. No. 112-74 § 7008, 125 Stat. 786, 1195 (2011); see also Jonathan Marcus, Egypt Turmoil: Coup or No Coup?, BBC NEws (July 4, 2013, 9:10 ET), http://www.bbc.co.uk/news/world-middle-east23180222?print=true, archived at http://perma.cc/RM6H-NKBZ ("So when is a coup d'etat not a coup? Or to put it another way, is there such a thing as 'a good coup', which means of course there must also be 'a bad coup'?'); see generally Nathan J. Brown, Redoing the Egyptian Revolution: How to Get The Transition Right This Time, ForEIGN AfFAIRS (July 3, 2013), http://www.foreignaffairs.com/articles/139555/nathan-j-brown/redoing-the-egyptianrevolution, archived at http://perma.cc/LGR9-JRCS.

65. Miller, supra note 63; see also Fisk, supra note 11; Nowara, supra note 11.

66. Max Fisher, Is what happened in Egypt a coup or a revolution? It's both, WASH.

Post WorldVIEWS BLOG (July 2013),

http://www.washingtonpost.com/blogs/worldviews/wp/2013/07/03/is-what-happened-inegypt-a-coup-or-a-revolution-its-both/, archived at http://perma.cc/4K6S-EAX4; Marcus, supra note 64.

67. Fisher, supra; see also Egypt Declares Muslim Brotherhood a Terrorist Group, Fox News (Dec. 25, 2013), http://www.foxnews.com/world/2013/12/25/egypt-declares-muslim- 
problematic and debatable to determine whether a coup has taken place when there are some indications that even the US government evaded a legal determination of the June 30 events and Morsi's ejection by the military. ${ }^{68}$

One should bear in mind that the US military and economic aids to Egypt were functioning under federal seizures and appropriations law requiring a Congressional certification that Egypt was meeting its obligations under the 1979 Egypt-Israel Peace treaty, and "[was] supporting the transition to civilian government including holding free and fair elections; implementing policies to protect freedom of expression, association, and religion, and due process of law." 69 Those requirements could be waived by the Secretary of State. ${ }^{70}$ No such waiver appears to be allowed in the case of a military coup. ${ }^{71}$ US Federal law allows aid to be reinstated only "if the President determines and certifies to the Committees on Appropriations that subsequent to the termination of assistance a democratically elected government has taken office." 72

Also, relating to international support of the current Egyptian régime from the Arab World, the current transitional government feels strongly that it can rely on the political and financial support historically provided by the economic cornerstones of the Middle Eastern and Gulf regions: Saudi Arabia, the United Arab Emirates (UAE), Bahrain, Jordan, and Kuwait. ${ }^{73}$ More importantly, the régime claims that the US and European Union

brotherhood-terrorist-group/, archived at http://perma.cc/6N5Q-JRKU; see also, Miller, supra note 63.

68. See Miller, supra note 63; see also David D. Kirkpatrick, Ousted General in Egypt Is Back, as Islamists' Foe, N.Y. TIMES, Oct. 30, 2013, http://www.nytimes.com/2013/10/30/world/middleeast/ousted-general-in-egypt-is-back-asislamists-foe.html?_r=0, archived at http://perma.cc/9BZ2-HNR2 ("General Sisi and the civilian ministers around him initially pledged to try to include Mr. Morsi's Islamist supporters in a new democratic process .... General Sisi appeared to consider the arguments of [the] former Vice President ... and a few others urging restraint in the interest of reconciliation with the Islamists .....") (alterations added).

69. Miller, supra note 63 (alteration added); see also Consolidated Appropriations Act, 2012, Pub. L. No. 112-74, § 7041(a)(1)(A)-(B), 125 Stat. 786, 1222 (2011). In other words, the U.S. will resume the military and economic support to Egypt until the temporary government takes the necessary essential steps to restore and back democracy and a democratically elected civilian government will be installed.

70. Consolidated Appropriations Act, 2012, Pub. L. No. 112-74, § 7008, 125 Stat. 786, 1195 (2011).

71. Id.

72. $I d$.

73. See Nicole Gaouette \& Caroline Alexander, U.S. Cuts Military Aid to Egypt, Seeks Move to Democracy, BloOMBerg (Oct. 9, 2013), http://www.bloomberg.com/news/201310-09/u-s-suspends-cash-and-equipment-assistance-to-egyptian-military.html, archived at http://perma.cc/7KDA-WGTN ("Since Mursi's ouster, the military-backed government has received pledges of at least $\$ 12$ billion in aid from Persian Gulf countries that oppose the Brotherhood, reducing the importance of financial support from the West. Egypt says it no longer needs International Monetary Fund loans."). 
States have no choice but to support it in order to maintain national security and economic interests in the Middle East, and to fight against radical terrorist organizations via counterterrorism programs. ${ }^{74}$

\section{A. Analysis on What Does and Does Not Constitute a Coup under the Egyptian Status Quo?}

According to the Supreme Constitutional Principles within the Egyptian legal framework the Head of State cannot be removed from power expect by majority approval of the People's Assembly. ${ }^{75}$ This principle has been confirmed in the various Constitutions through Egypt's history, including the latest de facto 2012 Constitution. ${ }^{76}$ In light of these constitutional standards and legal legitimacy, a President of the Republic should only be impeached if she commits a heinous criminal act, high treason, or equivalent acts related to the national security or public interests of the State. ${ }^{77}$ In these cases, the Speaker of the Parliament will act as an "Interim President," or, if the Parliament has dissolved, the Chief Justice of the Supreme Constitutional Court will be installed as an "Acting President." ${ }^{, 78}$ Therefore, the President will not be able to carry out any of his or her presidential powers as a "temporary barrier" until the trial, verdict, and sentence, regulated by the Constitution and the Penal Code, are reached. ${ }^{79}$ Once this "impeachment request" is issued by the required voting members in the Senate, the President will not be able to resume his presidential commitments as a "permanent or absolute barrier" and must

74. Id. ("The U.S. said it will cut military aid to Egypt until the army-backed government takes steps toward restoring democracy after the overthrow of President Mohamed Mursi and a crackdown on his Islamist supporters."); see also Egypt Condemns US Decision to Suspend Military Aid, BBC News (Oct. 10, 2013, 9:00 AM), $\mathrm{http} / / /$ www.bbc.co.uk/news/world-middle-east-24471148, archived at http://perma.cc/ZXA7-EDA7.

75. See Adel Mohamed, In Egypt, an Impeachment by the Masses, Not a Coup, News OBSERVER (July 8, 2013), http://www.newsobserver.com/2013/07/08/3017414/in-egypt-animpeachment-by-the.html\#storylink=cpy, archived at http://perma.cc/FDW8-V6U6.

76. See generally Nowara, supra note 11; Hayatsever, supra note 16.

77. See articles 151 and 152 of the de facto 2012 Constitution governing this issue in detail:

Constitution of the ARAB Republic of Egypt, 26 Dec. 2012, arts. 151-52, archived at http://perma.cc/LBJ6-QW8S [hereinafter 2012 Constitution]; but cf. CONSTITUTION OF THE ARAB Republic of EGYPt, 11 Sept. 1971, art. 85, as amended May 22, 1980, May 25, 2005, Mar. 26, 2007, archived at http://perma.cc/6EB6-YMTZ (replaced Mar. 20, 2011).

Thus, under the de facto 1971 Constitutional Charter, it is required that one-third of the People's Assembly vote to "request impeachment," which then has to be approved by twothirds of the body before impeachment proceedings could begin. Id.

78. 2012 Constitution, supra note 77, art. 153.

79. Id., art. 152 . 
stand on special trial. ${ }^{80}$ In light of that, what about characterizing the events of June 30 and the actions of July 3, 2013-from a constitutional perspective - as a "popular coup," or "common impeachment," and not a "military coup"?

\section{B. Popular Coup or Impeachment: A New Political and Legal Theory?}

In this domain, the al-qwaat al-moselaah(h) (military) was assisting the general public impeach or overthrow a president in the absence of any legal framework or with the non-existence of any constitutional procedures to do so. ${ }^{81}$ This Article holds that removal of the former Islamist President Mohammad Morsi represents a great deal of confusion not only in the West but also in the Arabian region. The reportage and coverage of the events were not based on a thoughtful and comprehensive understanding of the facts in objective terms of Egypt's modern history, specific national identity, or on the recent policies that led to this dramatic action.

Morsi was the first democratically elected civilian President according to official results of the general vote. ${ }^{82}$ The Egyptian Constitutional Charter of 2014 states that "Accusing the President . . . of violating the provisions of the Constitution, treason or any other felony must be based on a motion signed by at least the majority of the members of the House of Representatives," and that the motion "shall only be issued by the majority of two-thirds of the members of the House of Representatives." 83 Further, the Assembly has the authority to withdraw confidence and trust from the President and call for an earlier electionthrough a public referendum. ${ }^{84}$

80. Id. Also, Article 10 as amended by the Penal Law and the Law of the Criminal Procedure by Act No. 95/2003 provides that: A felony is an offence punishable by any of the following penalties: death, life imprisonment, aggravated detention, and simple detention. Law No. 58 of 1937 (Criminal Code of 1937, reformed in 1952), Al-Jaridaa Al-Rasmiyya, Aug. 1973, art. 80 (Egypt).

81. See generally Mohamed, supra note 75.

82. Jones, supra note 28; see also David D. Kirkpatrick, Named Egypt's Winner, Islamist Makes History, N.Y. TIMES, June 24, 2012, http://www.nytimes.com/2012/06/25/world/middleeast/mohamed-morsi-of-muslimbrotherhood-declared-as-egypts-president.html?pagewanted=all\&_r=0 ("Egypt's military rulers. . officially recognized Mohamed Morsi of the Muslim Brotherhood as the winner of Egypt's first competitive presidential election, handing the Islamists both a symbolic triumph and a potent weapon in their struggle for power against the country's top generals.") (alteration added).

83. See Constitution of the Arab Republic of Egypt, Jan. 18, 2014, art. 159 [hereinafter 2014 Constitution]. http://www.sis.gov.eg/Newvr/Dustor-en001.pdf, archived at http://perma.cc/9AF2-3RGW.

84. Id., arts. 160-162. Accordingly, the President will not be able to carry out any of his/her presidential powers as a "temporal barrier" until the referendum results are declared, if the majority voted against the President, an earlier election will take place within sixty 
Since there was no independent Parliament until Morsi's ouster, Egypt's Supreme Court dissolved the Parliament on an apparently legal basis, citing a misinterpretation of the law's provisions, the unconstitutionality of rules concerning independent candidates, and laws relating to political rights. ${ }^{85}$ Given the absence of a legally and constitutionally adequate instrument to impeach the sitting President, millions of Egyptians turned out to protest against him, asking that he respectfully step-down. ${ }^{86}$ At the same time, a national movement called tamarod [repel] collected more than twenty-two million petitions seeking the President's resignation and requesting earlier elections, principally because of the political failures that predicated the January 2011 uprisings. 87

In addition, the military submitted to the rule of law because it did not take over power, but promised to implement a road map towards real democracy during this "transitional period," one that included a new constitution and fresh parliamentary and presidential elections. ${ }^{88}$ Accordingly, the military installed the Chief Justice of the Egyptian Supreme (High) Court to serve as a temporary President until new elections were held. ${ }^{89}$

This Article argues that this sort of impeachment cannot be described as a "coup d'etat" in a technical and traditional legal sense. From a Western perspective, it is undoubtedly strange to see a military overthrow a democratically elected President, along with the rest of the government, and install itself as the ruling power while not declaring a coup. What happened on June 30 and July 3 was only military assistance to support Egypt's will to remove the dictatorial Morsi in whom the nation lost confidence and

(60) days from the announcement day of the official results and in this case the President will not be able to resume his presidential authorities as a "permanent or absolute barrier" and will be impeached. $I d$.

85. See Egypt Court Orders Dissolving of Parliament: High Court Rules Entire Parliament Should be Dismissed Because of "Constitutional Violations," AL-JAZEERA (June 14, 2012),

http://www.aljazeera.com/news/middleeast/2012/06/2012614124538532758.html, archived at http://perma.cc/S6AN-STL9.

86. See Shaimaa Fayed \& Yasmine Saleh, Millions Flood Egypt's Streets to Demand Mursi Quit, ReUTERS, Jun 30, 2013, http://www.reuters.com/article/2013/06/30/us-egyptprotests-idUSBRE95Q0NO20130630, archived at http://perma.cc/T7WA-8HN9.

87. See Michael O'Hanlon \& Tamara Wittes, What Next? International Community Must Show Ways Future Extremism Can Be Avoided, USA TODAY (July 4, 2013, 11:39 AM), http://www.usatoday.com/story/opinion/2013/07/04/michael-ohanlon-and-tamarawittes-on-what-next-in egypt/2489419/, archived at http://perma.cc/WB5P-CMSA.

88. Adel Mohamed, In Egypt, an Impeachment By the Masses, Not a Coup, NEWSOBSERVER.COM (July 8, 2013), archived at http://perma.cc/LU7N-KHZX.

89. See William Dermody \& Sarah Lynch, The Egypt Semantics Debate: Is It a Coup? A Civil War?, USA TODAY, (Aug. 16, 2013, 2:58 PM), http://www.usatoday.com/story/news/world/2013/08/16/egypt-coup-civil-war/2665313/, archived at $\mathrm{http}: / /$ perma.cc/XT9N-V7ZL. 
trust. The military merely acted on that collective sentimentality. Accordingly, the July 3 events were not a "military coup," but a "democratic (popular) coup" or "popular impeachment." This Article recommends that Egypt, a country undergoing the rising pains of an evolving democracy, should have an operative impeachment law. Particularly, an impeachment law that effectively deposes a President who obscures the law to preserve his grasp on power open-endedly, and a law that simultaneously defends and maintains political stability indispensable for economic growth and practical democracy. Otherwise, military interventions or frequent public revolts become the only available options. ${ }^{90}$

The following section discusses how laws can be based on religious norms, especially under the umbrella of Islamic law, via the flexibility of Sharia's definitions and interpretations, and how those laws fit within the new provisions of the 2014 Constitution.

\section{HOW LEGISLATION CAN BE FORMULATED ON RELIGIOUS NORMS - THE CASE OF THE EGYPTIAN CONSTITUTION OF 2014 AND ISLAMIC LAW}

Egypt's legal system is based principally on Napoleonic French Codes (civil law and not common law) and the flexible interpretation of Islamic law's main principles. ${ }^{91}$ After Egypt's colonization, it gradually came under foreign impact as the legal system began resembling European systems for commercial, civil, maritime, and penal laws; however, family (personal status) law remained governed according to Sharia law in the light of the dominant views of the Hanafi School of fiqh (jurisprudential) moderate thought. ${ }^{92}$

Sharia law influences the legal statutes and regulations in most Muslim countries. ${ }^{93}$ After the Arab Spring uprisings, a movement began to permit religious principles of Sharia law to govern not only family issues

90. For further details and proposal of an effective impeachment law in Egypt see Sahar F. Aziz, Egypt's Impeachment Alternative, CARNEGIE ENDOWMENT FOR INTERNATIONAL PEACE (Oct. 31, 2013), archived at http://perma.cc/EFL8-8YCD.

91. These Changes have been emphasized in the context of familial issue interpretation, practical application, and complete reform of the judicial administration, leading to the establishment of mukhtalatah (mixed) and ahli (national) courts; appeals are heard by regular justices in the Appellate Court and then the High Court (Court of Cassation). See generally Nathan J. Brown, The Rule of LAw IN THE ARAB World: COURTS IN EgYPT AND THE GULF (1997) (explaining various studies in the Egyptian legal system illustrating the court systems, crimes and punishments policy, law, and its correlation to the societal and transactional norms).

92. See Arafa, supra note 5, at 6; see also Khaled Abou El-Fadl, Reasoning with God: Reclaiming SHARI'AH IN THE MOdern Age (2014).

93. See generally EL-FADL, supra note 92; For further elaboration on this point, see generally Khaled Abou El-Fadel, Conceptualizing Shari'ah in the Modern State, 56 VILLANOVA L. REV. 803 (2012). 
concerning marriage, divorce, and inheritance, but also daily civil transactions. ${ }^{94}$ In the realm of family and criminal law, Sharia norms have incited a provocative debate. For example, some radical linguistic interpretations - which do not represent the accurate bulk of Sharia - of the Islamic provisions are used to rationalize the application of cruel penalties without adequate knowledge of the strict requirements for punishments such as hand amputation. ${ }^{95}$ In terms of democracy, modernity, and secularism, the argument for whether Islamic law's norms can exist alongside human rights norms, in particular with the integration of Islamic law principles in Middle Eastern and Muslim nations' future constitutions, is getting weaker. ${ }^{96}$

Legally speaking, the concept of "Islamic Sharia" has several technical meanings and gradually diverse impacts in Egypt than it often does in other Arabian countries, Europe, and the United States. ${ }^{97}$ Sharia means "path or right track." 98 It guides all features of Muslim life, comprising regular routines, familial and religious obligations, and even legal transactions (criminal, contractual, maritime, banking and financial, etc.). ${ }^{99}$ Islamic law as a divine, social, and legal order is derived mainly

94. See Robert Spencer, Egypt: Muslim Brotherhood Planning to Impose Sharia and Work Toward Restoration of Caliphate, JIHAD WATCH (June 27, 2012, 4:10 AM), http://www.jihadwatch.org/2012/06/egypt-muslim-brotherhood-planning-to-impose-shariaand-work-toward-restoration-of-caliphate/, archived at http://perma.cc/NA22-YY8T; see also Arafa, supra note 5, at 8 ("Personal family law affects every single Egyptian and is therefore possibly the most momentous area of law ... . [T] he term "personal status" itself, while widely used in Egypt today, does not derive from the Islamic legal tradition. But this was the one area of law that has been persistently cognizant by Sharie' $a$-based rules, up to the present-day. It is thus for historical and not religious perspectives that personal status has arisen as essential to Sharie' a debates.") (alterations in original) (footnotes omitted).

95. See M. Cherif Bassiouni \& Gamal Badr, The Sharia'h: Sources, Interpretation, and Rule-Making, 1 UCLA J. ISLAMIC \& NEAR E. L. 135, 150 (2002); see generally Khizr Muazzam Khan, Juristic Classification of Islamic Law, 6 Hous. J. INT'L. L. 23 (1983-1984); see generally THE IsLAMiC CRIMINAL JustiCE SyStem (M. Cherif Bassiouni ed., 1982).

96. See Clark B. Lombardi \& Nathan J. Brown, Do Constitutions Requiring Adherence to Shari'a Threaten Human Rights? How Egypt's Constitutional Court Reconciles Islamic Law with the Liberal Rule of Law, 21 AM. UNIV. INT'L. L. REV. 379 (2006).

97. See generally M. CHERIF BASSIOUNI, InTRODUCTION TO ISLAM (1985). As the second most popular religion in the world, and the fastest growing religion in Western Europe and the United States, Islam represents the ideological foundations for political institutions and the main source of law in many countries. See generally id. Moreover, Islamic law is an excellent subject for exploring the ideas of ethics, morality, and law because Islamic law purports to be a divine law, coming from Allah (God).

98. Although the exact English translation may differ between scholars, this is the author's own translation.

99. See generally M. Cherif BASsiouni, The Religion of Islam, in INTRODUCtion to ISLAM (1985), archived at http://perma.cc/GT5U-4PGF. Islam is therefore very much a "laworiented" religion. It designs the frame for acceptable economic, social and political systems, and articulates the ideologies and rules upon which laws and regulations can be recognized 
from the Quran'ic texts and the Sunnah (teachings of the Prophet Mohammad). ${ }^{100}$ Qiyyass (analogical deduction and precedents) and Ijtihad (individual reasoning) applied by Muslim 'Ulmmaa and Fuqqaha' a (jurists and scholars) are used to evolve new subjects. ${ }^{101}$ Moreover, the consensus of the Muslim Ummaa(h) (community) also plays a fundamental role in outlining this doctrinal and theological manual. ${ }^{102}$ Islamic fiqh (jurisprudence) is a significant part of the Sharia norms that endeavor to derive or formulate a rule of law in an issue whose rule is not mentioned in the primary sources of Islamic law, the Quran and Sunnah, but on the basis of the evidence found in those sources by a mujtahid (qualified jurist). ${ }^{103}$ From the Islamic jurisprudence notion, the fiqhal-madhhabs (schools of thought) in Islam have been derived and influenced by the development of Sharia. ${ }^{104}$ These schools grew and developed into distinct schools of law: the Sunni schools include Hanbali, Maliki, Shafi' $i$, and Hanafi, and the Shiie_a schools include the Twelve [Ja'ffari] school. ${ }^{105}$ Scholars of these

through which individuals should deal with one another. Islamic law is divided into two parts: ibadat (worship) rules and norms regulating the relationship between an individual and Allah (God), which is not secular and mo'amalat (transactions) guidelines and instructions governing the correlation between individuals and societal norms, which is changeable and develops according to time and place. Bassiouni \& Badr, supra note 95, at 135.

100. Bassiouni \& Badr, supra note 95, at 135 (defining Islamic law, detailing the main elements of Islamic law along with its various sources, and discussing the methodologies and schools of Islamic jurisprudence).

101. For further discussion on the subordinate sources of Islamic law, see generally Irshad Abdal-Haqq, Islamic Law: An Overview of Its Origin and Elements, 7 J. IsLAMIC L. \& Culture 27, 56 (2002) (defining the Sharie'a, highlighting its definition, sources, and its main schools of law).

102. Id.; see generally Ahmad Farrag Hussien, Al-Madkl Le Derassat Al-Sharie’a Al-Islamia: Al-Kitab Al-Awal [An Introduction to the Study of Islamic Sharie' A: Book I] (2006); see also Ramadan 'Ali Al-Shoronbasy, Al-MadKl Le Derassat AlFiqh Al-Islami: Al-Goze’e Al-Awal [An Introduction to the Study of Islamic JuRisPRUDENCE: Part I] 5 (2003).

103. See generally Nazeem Goolam, Ijtihad and Its Significance for Islamic Legal Interpretation, MicH. ST. L. REV. 1444-45 (2006) (discussing Ijtihad as a source of law in Islamic law, its definition, theoretical underpinnings, and historical development of the concept throughout the diverse ages of Islam); see also Bernard Weiss, Interpretation in Islamic Law: The Theory of Ijtihad, 26 AM. J. COMP. L. 199 (1978). In other words, individual reasoning refers to the understanding of Islamic rules and principles, as the fallible human effort to understand the content of that guidance. Id.

104. See John Esposito, Islam: The Straight Path 84-85 (3rd ed. 1998). In that sense, jihad has aspects other than the military one. "In light of that, one may understand latest interpretations of jihad as a civil society activism. The confusion regarding the Islamic concept of jihad happened as some writers unknowingly have used this word interchangeably with different words like al-harb ("war")." Adham A. Hashish, Ijtihad Institutions: The Key to Islamic Democracy Bridging and Balancing Political and Intellectual Islam, 9 Rich. J. GLOBAL L. \& Bus. 1, n. 13 (2010); see generally id.

105. See Hussien, supra note 102, at 120-122. The Hanafi perspective, known for being the most moderate and liberal school and focused on individual reasoning and analogy, is dominant among Sunnis in Egypt, Turkey, and others. See Hussien, supra note 102, at 124. 
schools vary their theories in terms of the weight applied to the following sources from which Islamic norms derive: the Quran, hadith, Islamic jurists, and the ijma'a (consensus) of the community. ${ }^{106}$ This variety has more influence on the legal systems of whole nations than on individual Muslims because many individuals do not follow one school in their private lives. $^{107}$

In 2011, Middle Eastern Countries such as Tunisia and Egypt ejected longtime tyrants and facilitated Islamist political parties, or what has been recently called "political Islam." that democracy is the best form of government, but at the same time there is strong support for Islam in politics. ${ }^{109}$ Muslim nations can benefit from the practical devices of better governance, administrative civil improvements, open media, and public debate, while prohibiting the arbitrary use of power-all areas in which they are generally lacking. ${ }^{110}$ Most conservative Muslim intellectuals argue that nations that have accepted and implemented Islamic law should also permit judicial review, under which interpretations of the Sharia should be widened to take into consideration historical, ethnic, and political circumstances. ${ }^{111}$ On the contrary, several radical Islamists are opposed to the judicial review technique, claiming that the Quran'ic provisions and Sharia norms are sacred and are to be taken literally. ${ }^{112}$ In the same vein, modern Islamic jurists argue that Islam requires a democratic system and the basis of democracy has been addressed by the Quran'ic texts because Shoura (mutual consultation) among the folks is applauded. ${ }^{113}$ Other scholars claim that democracy is a Western notion

On the other hand, the Hanbali School of law known for following the most orthodox form of Islamic law is adopted in Saudi Arabia. See Hussien, supra note 102, at 126. The Maliki School is prevailing in North Africa and the Shafi' $i$ attitude in Malaysia, Indonesia, and Yemen. See HusSIEN, supra note 102, at 130-135.

106. See generally Youssef KASSEm, MASAder Al-FiqH Al-Islami [Sources of ISLAMIC LAW] 65 (2000).

107. Id.; see HuSSIEN \& AL-Shoronbasy, supra note 102.

108. Marco Werman \& Matthew Bell, Where does Political Islam in Egypt Go from Here?, PRI's THE WORLD (Aug. 19, 2013, 9:30 AM), http://www.pri.org/stories/2013-0819/where-does-political-islam-egypt-go-here, archived at http://perma.cc/UXL7-YLFE.

109. See Eric Trager, The Islamic Insurgency That Could Soon Hit Egypt, THE WASHINGTON INSTITUTE (Aug. 19, 2013), http:/www.washingtoninstitute.org/policyanalysis/view/the-islamic-insurgency-that-could-soon-hit-egypt, archived at http://perma.cc/Z4P2-H96E.

110. See Timothy Stanley, An Islamic State in Egypt Can Still Mean Democracy, CNN (June 27, 2012), http:/www.cnn.com/2012/06/27/opinion/stanley-morsi-islam/, archived at http://perma.cc/D45C-FE9S.

111. See generally David S. Powers, On Judicial Review in Islamic Law, 26 LAw \& Soc'y ReV. 2, 315 (1992); see also DisPensing Justice IN Islam: QADIS AND THEIR JudGMENTS 299-319 (Muhammad Khalid Masud et al. eds., 2005).

112. Powers, supra note 111, at 315.

113. See QUR'AN 42:38, archived at http://perma.cc/MRA7-QUMD (providing accurate English translation of the Qur'an); see also Jawad Sadek Sulaiman, The Shura Principle in Islam, 9 The ARAB American Dialogue 2, at 19-22 (1997). The distinction is important to 
enforced on Muslim states. ${ }^{114}$ And yet other intellectuals have argued that instead of refusing democracy, many Muslims understand Sharia as "a means to be liberated from government corruption and believe it can exist within a democratic and inclusive framework." 115 Other scholars contend that maintaining a secular government is the greatest way to identify Sharia norms, as Professor An-Na'im said, "Enforcing a [Sharia] through the coercive power of the State negates its religious nature, because Muslims would be observing the law of the State and not freely performing their religious obligation as Muslims." ${ }^{, 16}$ Muslim jurists have tried to make balance between Islamic and secular law, accordingly, Sharia in the Arabian region has been combined into political systems in three general classical features as follows.

\section{A. Governmental System under God (Divine Law)}

Several Muslim Countries' constitutions declare Islam as their official religion. ${ }^{117}$ Sharia is therefore declared to be a source, or the source, of their legislation. ${ }^{118}$ These régimes draw their legitimacy from Islam as a religion and legal order. ${ }^{119}$ Examples include Saudi Arabia, Jordan, Bahrain, Iran, and others. ${ }^{120}$ In these countries it is illegal to enact and

note, because the Qur'an has left it to successive generations of Muslims to continue to endeavor toward a more faultless realization of the Shoura principle. God says: "Those who hearken to their Lord, and establish regular prayer; who conducts their affairs by mutual consultation; who spends out of what We bestow on them for sustenance are praised." QUR'AN 42:37. "Thus it is due to mercy from God that you deal with them gently, and had you been rough, hard hearted, they would certainly have dispersed from around you; pardon them therefore and ask pardon from them, and take counsel with them in the affair; so when you have decided, then place your trust in God; surely God loves those who trust." QUR'AN 3:159.

114. Powers, supra note 111.

115. See generally John L. Esposito \& John O. Voll, Islam and Democracy, 22 HUMANITIES 6 (2001), archived at http://perma.cc/W8P5-J7PW.

116. See Abdullahi Ahmed An-nA'im, Islam and the Secular State: Negotiating THE FUTURE OF SHARI'A (2009) (explaining the relationship between religion and the secular state in all societies).

117. See Mohamed Arafa, Corruption and Bribery in Islamic Law: Are Islamic Ideals Being Met in Practice?, 18 AnN. Surv. InT'L. \& CoMP. L. 171, 183 (2012).

118. Id. at 183-4.

119. Id.

120. See, e.g., Constitution of the Kingdom of Bahrain, Feb. 14, 2002, art. 2 (implementing Islamic law as the main source of law in Bahrain); ISLAHAT VA TAQYYRATI VA TATMimAH QANUni AsSASsi [AMENDMENT to the Constitution] 1989, arts. 4, 12 (Iran), archived at http://perma.cc/R8TD-SMC4 (providing that "[t]he official religion of Iran is Islam and the Twelver Ja'fari [Shi'aa ] school" and that "[a]ll civil, penal, financial, economic, administrative, cultural, military, political, and other laws and regulations must be based on Islamic criteria"); THE CONSTITUTION OF THE HASHEMite KingdOM OF JoRdAn, Jan. 1,1952 , art. 2 (providing that "Islam is the religion of the State"); CONSTITUTION OF THE United ARAB Emirates, Dec. 2, 1971, art. 7 (providing that "[ $\mathrm{t}]$ he Islamic Shari' ah shall be 
endorse statutes or legal regulations that are in conflict with Islam. ${ }^{121}$ The making and modeling of new constitutions in the Arab Spring countries has led to a discussion about the role of Islamic law in a democracy. ${ }^{122}$ It should be noted that Non-Muslims, such as Coptic Christians in Egypt, are not expected to follow the Islamic norms. In most countries, they are under the jurisdiction of distinctive committees, especially with family law issues, and adjunct courts under government control. ${ }^{123}$

\section{B. Entirely Materialistic (Secular)}

It should be noted that some Muslim countries recognize secular practice and lifestyles in their constitutional charters, including Chad and Tajikistan among others. ${ }^{124}$ Secular Muslim nations are a minority, and the admiration of Islamist political parties' victories amongst the people in Muslim nations is tapering the gap between state and religion. ${ }^{125}$ In these countries, Islamic values frequently stimulate indigenous customs. ${ }^{126}$ Generally speaking, Islamist organizations are regularly observed as a potential threat by governments of secular Muslim countries, and thus, these governments often crack down on such political groups and parties. ${ }^{127}$

\section{Dual Legal Structure}

Several popular Muslim nations have a double system in which the government is liberal [secular] but Muslim individuals have the option to bring commercial, civil, and familial disputes to Sharia courts. ${ }^{128}$ In some

a main source of legislation").

121. KASSEM, supra note 106.

122. See generally Clark B. Lombardi, Designing Islamic Constitutions: Past Trends and Options for a Democratic Future, InT'L. J. OF CONST. L. (2013) (discussing some of the qualities that effective democratic Shari'a Guarantee Clauses enforcement schemes); see generally Clark B. Lombardi, State Law As Islamic Law in Modern Egypt 49-58 (2006); Erwin J. Rosenthal, Political Thought in Medieval Islam, $43-61$ (1958).

123. Lombardi, supra note 122; see also Arafa, supra note 5, at 13-14.

124. Nisrine Abiad, Sharia, Muslim State, and International Human Rights Treaty Obligations: A Comparative Study, 51 BRIT. InST. INT'L. \& COMP. L. (2008) (illustrating the relation between religion and State in Middle East).

125. Id.; see also RoSENTHAL, supra note 122.

126. See generally Ahmet T. Kuru \& Alfred Stepan, Democracy, Islam, and SECUlARISM IN TURKey (2012) (examining issues relevant to Turkish debates and global concerns, from the State's position on religion to its involvement with the European Union) ("While Turkey has grown as a world power, promoting the image of a progressive and stable nation, several choices in policy have strained its relationship with the East and the West. Providing historical, social, and religious context for this behavior, the essays in Democracy, Islam, and Secularism in Turkey.").

127. Id.

128. See Soeren Kern, Britain's Sharia Courts: You Cannot Go Against What Islam Says, GateStone Institute, International Policy Council (Apr. 23, 2013), http://www.gatestoneinstitute.org/3682/uk-sharia-courts, archived at http://perma.cc/W5TQ- 
countries, such as Tanzania, the civil courts apply Islamic law or secular law based on the religious backgrounds of the defendants while others such as Lebanon, have muktalataa(h) (mixed jurisdiction) courts based on religious sects and residual foreign legal systems enhanced by Sharia. ${ }^{129}$ In this regard, some Western governments such as the United Kingdom are also considering the notion of permitting Muslims to apply Islamic law in commercial, family, and financial conflicts. ${ }^{130}$ However, others, such as the state governments of Oklahoma and North Carolina in the United States, are in favor of banning the use of Sharia law in litigation. ${ }^{131}$

\section{Islamic Business Law: Sharia and Modern Economics, any Clashes?}

Islamic business law, including banking and finance, works as an international industrial tool that changes and adjusts to modern commercial and business practices while being consistent with Sharia law rules and objectives. ${ }^{132}$ Scholars argue that "Islamic finance is a way to put Islamic principles about the economy into practice." ${ }^{\prime 33}$ Two foremost financial rules that appear recurrently in the Quran'ic texts and Sunnah's teachings are proscriptions against ribaa(h) (usury or interest) and gharar (excessive

BUW7.

129. Id.; see also Noah Feldman, Why Shariah?, ThE N.Y. TIMES, Mar. 16, 2008, http://www.nytimes.com/2008/03/16/magazine/16Shariah-t.html, archived at http://perma.cc/B4CR-L9VY ("[S]ubject to the agreement of all parties and the strict requirement of protecting equal rights for women, it might be a good idea to consider allowing Islamic and Orthodox Jewish courts to handle marriage and divorce.") (alteration added).

130. See Daveed Gartenstein-Ross, Has Britain "Adopted Islamic Law"?, ThE WeEKLY STANDARD, Sept. 19, 2008, http://www.weeklystandard.com/weblogs/TWSFP/2008/09/has_britain_adopted_islamic_la_ 1.asp, archived at http://perma.cc/V7DW-2SFA ("The government has quietly sanctioned the powers for sharia judges to rule on cases ranging from divorce and financial disputes to those involving domestic violence. Rulings issued by a network of five sharia courts are enforceable with the full power of the judicial system . ....") (alteration added).

131. Joel Siegel, Islamic Sharia to be Banned in, ah, Oklahoma, ABC News, (June 14, 2010), http://abcnews.go.com/US/Media/oklahoma-pass-laws-prohibiting-islamic-sharialaws-apply/story?id=10908521, archived at http://perma.cc/5EWE-UX6L; see Elaine Sciolino, Britain Grapples With Role for Islamic Justice, THE N.Y. Times, Nov. 19, 2008, http://www.nytimes.com/2008/11/19/world/europe/19shariah.html?_r=0\&pagewanted=print, archived at http://perma.cc/85ZT-MFK3; see also Matthew Brown, North Carolina Becomes 7th State to Ban Muslim Sharia Law, Deseret News (Aug. 28, 2013, 6:50 AM MDT), http://www.deseretnews.com/article/865585340/North-Carolina-becomes-7th-state-to-banMuslim-Sharia-law.html?pg=all, archived at http://perma.cc/L8C9-6XZM.

132. Mohammad Hashim Kamali, Principles of Islamic Jurisprudence (3rd ed. 2003).

133. See Hans Visser, Islamic Finance: Principles And Practice 1 (2009) (illustrating the notion of al-gharar contracts and gambling and their prohibition in Islamic law in order to prevent disputes and to protect the weaker parties to an agreement). 
risk). ${ }^{134}$ It should be noted that ingenious twists on customary and ordinary fiscal and monetary products such as savings and checking accounts, credit cards, banking loans, mortgages, loans, stocks, sukuk (bonds), and others financial instruments evade the classical business ideal. ${ }^{135}$ Some of the morally-minded are also switching to Sharia-compliant investments, securities, and some entrepreneurs are evading forbidden transactions such as trading in hedonistic industries like pornography. ${ }^{136}$ By dealing with Sharia-compliant entities stakeholders are ensuring that their cash will not end up sponsoring what they consider immoral activities. ${ }^{137}$ Some current Islamic governments are looking to launch Sharia-compliant financial devices that do not conflict with Islamic values. ${ }^{138}$

\section{Islamic Criminal Law: Do Islamic Penalties Conflict with Principles of Equality and Human Rights?}

In Islamic criminal Sharia law, there are three categories of criminal acts. ${ }^{139}$ The first includes Quesas (equivalence) and Diyyaa $(h)$ (compensational) offenses which state that an individual who has committed a specified criminal act will be punished in the same way and by the same means that she used in hurting the other person. ${ }^{140}$

134. See id. at 31-48; see also Brian Kettell, Case Studies in Islamic Banking And FINANCE 52 (2011) (explaining the commercially prohibited activities under Islamic law including usury: "al-ribba(h)"). God says, "O you who have believed, do not consume usury, doubled and multiplied, but fear Allah that you may be successful." QUR'AN 3:130; "And whatever you give for interest to increase within the wealth of people will not increase with Allah. But what you give in zakāt(h), desiring the countenance of Allah-those are the multipliers." Id. at 30:39; "The Gharar sale includes selling fish that are in water, selling a slave that has escaped, selling birds that are in the sky, and similar sales." Id. 17:1230.

135. In this domain, enormous international banks such as HSBC, Citigroup, etc. have established Islamic banking sectors to provide to several demands. Bilal Khan \& Emir Crowne, The Value of Islamic Banking in the Current Financial Crisis, 29 REV. BANKING \& FIN. L. 441, 446 (2010) (outlining the central concepts of Islamic banking, how many of the common financial instruments of that system and proposing that the Western financial crisis could have been prevented, or at least alleviated, by adherence to Islamic banking principles, and how the recent credit crisis in the Middle East could have been avoided through stricter adherence to Islamic banking principles).

136. See generally Barbara L. Seniawski, Riba Today: Social Equity, the Economy, and Doing Business under Islamic Law, 39 COLUM. J. TRANSNAT'L L. 701 (2001) (addressing the debate within Islamic law concerning the ribaa(h)'s interpretation generally and the impact of its prohibition on interests in modern businesses).

137. Id.

138. Id. at 725-26.

139. Arafa, supra note 117 , at 193.

140. Arafa, supra note 117 , at $189-90$ (explaining the requirements of each mode of Islamic criminal evidence and the taxonomy of crimes and penalties in Islamic criminal law) ("There are five Quesas crimes: murder, voluntary or intentional killing or manslaughter, involuntary killing, intentional physical injury or maiming, and unintentional physical injury 
The second category is hudud (fixed) offenses, those that are prescribed an explicit and precise punishment in the Quran. ${ }^{141}$ There are seven hadd criminal acts: fornication, drinking alcoholic beverages, theft, apostasy (with some debate), highway robbery, defamation and slander, and rebellion against legitimate authority. ${ }^{142}$ Punishments for these offenses cannot be applied unless the strict conditions of their application have been fulfilled. ${ }^{143}$

Ta'azir is the third group of misconducts in Islamic law, which includes all wrongdoings for which Sharia does not propose a punishment. ${ }^{144}$ Sanctions for these crimes emerge from the discretionary power delegated to the Qadi (judge). ${ }^{145}$ Notwithstanding official unwillingness to use hudud punishments, honor (family) killings - reprisals for bringing dishonor on one's family-pubertal (young) zawajs (marriages), polygamy, gender mixture and gender equality, and inheritance rules, all of which are universal in Muslim countries, are still in debate. ${ }^{146}$ In the same vein, there is a noteworthy discussion over what the main source of Sharia law (the Quran) actually says and what principles were just dragged from local customs that predate Islam. ${ }^{147}$ Few scholars argue

or maiming. These criminal acts are defined both in the Qur'an and Sunnah and establish two sorts of sanctions: retaliation (the principle of 'Talion') and Diyyah ('Legal Compensation')"). Crimes of blood are punished either by retribution or by compensation. Only victims and their representatives possess the right to prosecute the criminal; the public authorities have no power to intrude. "Regarding the legal compensation, the victim's family may ask for payment within the period of time when the exercise of retribution is still permitted. However, any compensation must meet the requirement of the consent of the perpetrator." $I d$. at 191 (explaining the requirements of each mode of Islamic criminal evidence and the taxonomy of crimes and penalties in Islamic criminal law).

141. See id. at 193.

142. Id. at 191.

143. Id. For example, punishment for theft is the amputation of hand, flogging for drinking wine, exile, or local banishment, and these penalties are not often prescribed. Id.

144. See Arafa, supra note 117, at 193.

145. Arafa, supra note 117, at 219-20.

146. See generally Claude Salhani, Open the Gates of Ijtihad, Common Ground News SERVICE (Mar. 14, 2006), http://www.commongroundnews.org/article.php?id=2579\&lan=en\&sp=1, archived at http://perma.cc/7W9S-ZDU7 ("The solution to the turmoil gripping Muslim society today may be found in reintroducing ijtihad. Re-opening the gates of ijtihad will allow Muslims to reinterpret Islam for the 21 st century' . . . . 'The practice of ijtihad' . . . the participation of several respected Muslim scholars, 'must be revived.' Ijtihad-or hermeneutics - refers to the institutionalized practice of interpreting Islamic law (sharia'h) to take into account changing historical circumstances and, therefore, different points of view.") (alterations added). In the same vein, there is a noteworthy discussion over what the main source of the Sharie' a law (the Quran) actually says and what principles were just dragged from local customs that predate Islam.

147. Id.; see Arafa, supra note 117, at 182; see also Mohamed A. Abdelaal, Taqlìd v. Ijtihād: The Rise of Taqlìd as the Secondary Judicial Approach in Islamic Jurisprudence, J. JURIS 151 (2012) (expounding taqlìd in its judicial aspect as the secondary Islamic judicial approach in an attempt to apply its concept on the proper Islamic judge). 
to eradicate or at least alter these contentious and questionable principles of criminal law by citing the religious tenet of tajdid (modernity) through ijtihad (individual reasoning) policies. ${ }^{148}$ Although a few jurists share this modern perspective, others consider the correct form of Islamic law to be the one experienced in the seventh century. ${ }^{149}$ This Article now turns to the question of whether the role of Sharia has changed in light of the new 2014 Egyptian Constitution.

\section{What's NeXT AND NEW IN THE 2014 CONSTITUTION AFTER MORSI's OUSTER?}

The top country-specific priority of Western governments, especially the United States, for Egypt, is the existence of a constitutional document based on the rule of law, guaranteeing human rights including minorities' and women's rights; thus, for these nations and according to this Article's stance: the Constitution cannot be based on a misinterpretation and misapplication of Islamic law. ${ }^{150}$ The recent debates on the Egyptian Constitution have focused on economic consequences, women's rights (electoral representation and employment rights, for example), ensuring religious freedom, maintaining stability without constant terrorist activities, and overall noticeable progress for the social and economic health of the country. ${ }^{151}$

Historically, Egypt's Constitutions have caused enforcement of its Sharia Guarantee Clauses through judicial review by Egypt's Supreme

148. See The Importance of Learning the Meaning of Ijtihad, PASCAL'S VIEW (Feb. 24, 2006), http://www.pascalsview.com/pascalsview/2006/02/the-importance-of-learning-themeaning-of-ijtihad.html, archived at http://perma.cc/TG3V-RD3Y

("Ijtihad is a technical term of Islamic law that describes the process of making a legal decision by independent interpretation of the legal sources, the Qur'an and the Sunnah. The opposite of ijtihad is taqlid (imitation). A person who applied ijtihad was called a mujtahid, and traditionally had to be a scholar of Islamic law or 'alim.").

149. Id.; see also Mohammad Hashim Kamali, A Collective Ijtihad for Solving Society's Problems, COMMON Ground News SERvice (Mar. 14, 2006), http://www.commongroundnews.org/print_article.php?artId=2580\&dir=left\&lan=en\&sid=1, archived at http://perma.cc/U5E2-2S9W.

150. See generally Jeremy M. Sharp, Cong. ReSEarch Serv., R43183, Egypt in Crisis: ISSUES FOR CONGRESS (2013), archived at http://perma.cc/GK6A-E2EG (outlining the key issues for Congress related to Egypt) ("U.S. policy makers are now grappling with complex questions about the future of U.S.-Egypt relations, particularly in light of the growing unrest and violence currently unfolding.").

151. For further details on this point, see Katrina Lantos Swett, Egypt's New Constitution: Challenges for Religious Freedom and Related Rights, GEORGETOWN J. OF INT'L. AfF. (Mar. 21, 2013), http://journal.georgetown.edu/2013/03/21/egypts-newconstitution-challenges-for-religious-freedom-and-related-rights-by-katrina-lantos-swett/, archived at http://perma.cc/ZH78-E5RM. 
Constitutional Court. ${ }^{152}$ The use of Sharia Guarantee Clauses was an attempt to modernize Egypt within the interpretation of Islamic law's revival, but Islamists, whose interpretation of Islam was partly but not entirely liberal, have found issue with the Clauses. ${ }^{153}$ Under former President Anwar el-Sādāt, in 1980, the Egyptian government amended article 2 of the Constitution to read "principles of the Islamic Sharia are the principal source[s] of legislation," and this provision can be clearly understood as a Sharia Guarantee Clause. ${ }^{154}$ In this regard, the Court held it had no jurisdiction over article 2 remedies or challenges to legislation that had already been enacted or in force at the time the article was endorsed, but it did have authority to hear challenges and disputes to any laws passed afterwards. $^{155}$

The ruling of the High (Supreme) Court seems to have confirmed that the government's new obligations to Islam did not exclude the sort of liberalization that the justices were trying to stimulate through their decisions around this time. Meanwhile, Egypt's Islamists (the Muslim Brotherhood) continuously struggled with that notion and claimed that only "customarily trained" scholars can be trusted for interpreting Islamic law rules-yet many of their leaders had no traditional training and have minimal knowledge about the basics of Islamic law. ${ }^{156}$ Most significantly, the Court used a technique and process that was deeply indebted to substantial modernization, but one that also made signals towards more traditional approaches and classical methods of interpretation. ${ }^{157}$

In a landmark judgment, the Court elucidated these "principles" and defined them as the "Sharia injunctions, which are peremptory in proof (of

152. It should be noted that this court is in charge of reviewing the constitutionality of statutes and regulations (decrees). For further details on the High Court in Egypt, see generally Tamir Moustafa, The Struggle for Constitutional Power: Law, Politics, AND ECONOMiC DEVELOPMENT IN EGYPT (2007).

153. See Nathan J. Brown, The Rule of Law in the Arab World: Courts in Egypt AND THE GULF 93-96 (1997).

154. See 2012 Constitution, supra note 77, art. 2 (alteration added); see also Clark B. Lombardi, Constitutional Provisions Making Sharia " $A$ " or "The" Chief Source of Legislation: Where Did They Come from? What Do they Mean? Do They Matter?, 28 AM. U. INT'L. L. REV. 733, 755-58 (tracking Egypt's constitutional history regarding the application and implementation of Islamic law).

155. Rector of the Azhar Univ. v. President of the Republic, Case No. 20 of Judicial Year No. 1 (Sup. Const. Ct. 1985), translated in 1 ARAB L.Q. 100, 104 (Saba Habachy trans., 1986).

156. See generally Megan L. McMillan, Note, Egypt's Interpretive Incorporation of Human Rights: the Supreme Constitutional Court's Use of International Sources and Prospects for its Article 2 Analysis, 16 Transnat'L L. \& Contemp. Probs. 1089 (2007) (providing a timeline of the Brotherhood into present day where their influences on the law are political and financial, but lacking in scholarly legitimacy).

157. See Lombardi, supra note 122, at 22-24. 
origin) and significance," and governmental application of the variety of understandings and rulings that date back to the tenth century (extreme and radical Islamism). Moreover, the Court stated that the constitutional provision in question was addressed to lawmakers (not to justices) and that it was not applicable retroactively on prevailing laws. ${ }^{59}$ Further, the Court pointed out "that Islam and its whole rules must be interpreted to be consistent and in conformity with liberal standards comprising not only contractual, commercial, maritime, labour, property and other daily transactions but also human rights, including women and minority rights."

The Supreme Constitutional Court-and now many Egyptian intellectuals and political figures - have come to see the Islamic Sharia as suitable and relevant to modern positive law in two manners. First, the Sharia is based on definite common objectives or maqasid/darouriat (such as the protection of life, lineage, property, religion, and prosperity), a concept which appeared from medieval classical jurisprudence. These objectives should guide legal experts and Muslim Ulm'aa/Fuqha'aa (jurists) in defining and formulating the law in difficult circumstances, but also, progressively, by non-experts who claim that the maqasid have to be extended beyond tradition to contain objectives like freedom. ${ }^{161}$ Second, regarding the diversity in Islamic orthodox legal traditions, it is agreed that a small number of rulings founded in the primary sources are accurate and verified (ahkamm qat'h al-sbout wa al-delalah) such that they cannot reasonably be disclaimed and hence must be followed. ${ }^{162}$ After Mubarak's overthrow, the Muslim Brotherhood dominated the parliamentary elections and won the presidential election, and some members anticipated modifying Egyptian law to permit the legislature to override the Supreme Constitutional Court - causing much tension between the Muslim Brotherhood, the Court, and the general public. ${ }^{163}$ In the de facto 2012 Constitution, there were provisions that instructed the Supreme Constitutional Court to follow more classical interpretations of Islam and a

158. Adel Guindy, Sharia and the New Egyptian Constitution, FrontPage Mag, Nov. 26, 2013, http://www.frontpagemag.com/about/, archived at http://perma.cc/33WE-T67U.

159. See Arafa, supra note 5, at 10.

160. Guindy, supra note 158.

161. Arafa, supra note 5, at 10; see generally WiLLiAm MONTGOMERY WATt, THE FAith AND PRACTICE OF AL-GHAZALi (1963) (illustrating al-Ghazali's attitude on the five essentials of Islamic law).

162. Arafa, supra note 5, at 10; see generally Nathan J. Brown \& Amr Hamzawy, The Draft Party Platform of the Egyptian Muslim Brotherhood: Foray Into Political Integration or Retreat Into Old Positions?, 89 CARnegIe PAPERs: Middle EAST SERIES 1 (2008).

163. See Egypt Reels from Judicial Coup, ThE GuARDiAn (June 15, 2012), http://www.guardian.co.uk/world/middle-east-live/2012/jun/15/egypt-reels-judicial-couplive, archived at http://perma.cc/767W-QNT2. 
more strict understanding of Islamic law. ${ }^{164}$

The new Constitution that had been written involved a handful of Islamists, making it vulnerable to comparable charges of excluding or eliminating. The new Charter emphasizes exactly the correlation between state and religion and confirms religion's separation from political scenes. ${ }^{165}$ This document eradicates all religious references and vague language including the term "public morals" which now represents a new form of guarantees and protections for women and religious minorities. ${ }^{166}$ Personal and familial status is completely based on Sharia law and issues related to adoption, inheritance, or guardianship apply to non-Muslims as well. ${ }^{167}$ Most notably, article 2 and its complement 219 had an overwhelming effect on Egypt under Morsi, which implicitly converted the national identity of the country to a theocracy and could be used to justify the treatment of non-Muslims as second class citizens and set the groundwork for the process of the Islamization of the nation. ${ }^{168}$ Although

164. In other words, the Court can keep its substantially moderate jurisprudence only insofar as it can persuasively make an argument for it in terms that fundamentalists and traditional modernists will approve. For more information on these articles, see Clark B. Lombardi \& Nathan J. Brown, Islam in Egypt's New Constitution, ForeIGN POLICY (Dec. 13, 2012), archived at http://perma.cc/AK8U-BKYW. For further details on the Islamist Egyptian Constitution of 2012, see generally Mohamed Arafa, Egypt Between Fear and Reform in its Second Revolution: The Failure to Protect the Fundamental Human Rights Over And Over Again, 7 Phoenix L. ReV. 1 (2013) (analyzing the important articles that were designed for opening the door to the theocratic paradigm, amplifying the role of Islamic law, the misuse of its application, and restricting freedoms which led to the June 30 events and proposing amendments considered by the Constitutional Committee in charge of amending the 2012 de facto Constitution).

165. See generally Gamal Essam El-din, Egypt's Constitution Will Oblige Parliament to Regulate ChurchConstruction, AhrAmonline (Nov. 30, 2013), http://english.ahram.org.eg/NewsContentPrint/1/0/87896/Egypt/0/Egypts-constitution-willoblige-parliament-to-regu.aspx, archived at http://perma.cc/Y29D-MYCT ("[a] newly added article in Egypt's draft constitution aims to allow Christians to 'perform their religious rites freely."') (alteration added).

166. Id. ("Egypt's new constitution . . . includes an article that will oblige the coming parliament to issue a law regulating the building and restoration of churches.") (alteration added).

167. See generally Nathan J. Brown, Egypt's Constitution: It's Not Really about the Religious Clauses, THE GUARDIAN (Feb. 15, 2012), http://www.theguardian.com/commentisfree/2012/feb/15/egypt-constitution-religious-

clauses, archived at http://perma.cc/7BVT-GEGU ("[m]any voices are coming together to write the constitution-but how will Egypt's power centers work together in the new State?") (alteration added).

168. See New Coptic Orthodox Patriarch Says No to Shari'a-Inspired Constitution, ASIANEws (Nov. 6, 2012), http://www.asianews.it/view4print.php?1=en\&art=26282, archived at http://perma.cc/B9VX-E22X ("In his first press release, Anba Tawadros II speaks out against Islamism's growing stranglehold on Egyptian society. For the head of the Coptic Church, Egypt is a great country because it is home to Christians and Muslims.") (alteration added). 
Christian Copts represent 12 to 15 percent of the country's population, their representation is very minimal in the military, police, judiciary, diplomatic corps, university posts, media, and other similar posts under the unrecorded rules on relegation. ${ }^{169}$ The failed attempt to base the 2012 de facto Constitution on the misuse of Islamic law jurisprudence via extreme Islamism and a theocratic paradigm provided for government endorsed discrimination against all religious minorities, including Muslim minorities (Shii'aa, Ahmadies), Christians, Jews, and Baha'i (one of the nonAbrahamic beliefs), who have all in several ways existed as second-class residents. ${ }^{170}$ The overthrow of the Morsi administration by people and the military along with the abrogation of the 2012 Constitution saved Egypt from the direct misapplication of the Sharia and a return to the European dark ages. ${ }^{171}$ A full accumulation of difficulties would increase based on such institutionalized inequality. ${ }^{172}$ However, Egypt has signed international conventions and universal documents such as the International Covenant on Civil and Political Rights (ICCPR), which guarantees full religious freedom under article 18, while the now repealed 2012 Egyptian Constitution was vague on this public right. ${ }^{173}$ In light of all these

169. Arafa, supra note 23 , at 7-8.

170. Arafa, supra note 164, at 35.

171. Charlene Gubash, As Morsi Takes Symbolic Oath, Many Fear the 'Islamization of Egyptian Society, World News (June 29, 2012), http://worldnews.nbcnews.com/_news/2012/06/29/12484697-as-morsi-takes-symbolic-oathmany-fear-the-islamization-of-egyptian-society, archived at http://perma.cc/6RVD-JXFK (noting concerns of the Egyptian Coptic community and advocates of women's rights).

172. Id. Some examples of typical misunderstandings of Islamic law and, of course, the misapplication of its injunctions include:

a. The misapplication of the severe bodily punishments, such as stoning, the amputation of limbs, crucifixion, or flagellation without the fulfillment of its strict conditions and high proof standards;

b. That a non-Muslim's court testimony cannot be admitted against a Muslim; c. That a Muslim killer of a non-Muslim cannot get the death penalty; and d. The requirement? of "Virtue and Vice Police" and others who "correct" the practices of citizens, which we keep seeing in various Muslim and Arabian nations.

Id.

173. See Arafa, supra note 164 , at 187,189 . This in practice means that the government would recurrently repudiate religious freedom to minorities except the three recognizable "heavenly" religions of Islam, Judaism, and Christianity. Additionally, apostasy (conversion away from Islam to another faith), which is a debatable issue in Islamic law, was chiefly forbidden by the State, and those who tried to reject Islam were arrested, or tortured by the security forces, and when radicals beat and even killed apostates the government would not interfere or mediate. See generally The International Covenant on Civil and Political Rights, art. 18, March 23, 1976, vol. 999 U.N.T.S. 171, archived at http://perma.cc/WK77-74FW, (opened for signature Dec. 19, 1966); The Universal Declaration of Human Rights, art. 18, Dec. 10, 1948, archived at http://perma.cc/MQ7M-D3KR (noting the requirement of absolute freedom of religion). 
shortcomings in the 2012 Constitutional Charter, the role of Islamic law and its interpretation and application to protect the rights and freedoms of all Egyptians is very obvious in the new 2014 Constitution.

Article 2 still remains in the de facto 1971 and 2012 Constitutions with no reference to any vague religious or moral concepts and stipulates that "[I]slam is the religion of the State and Arabic its official language. Principles of Islamic Sharia [law] are the principal source of legislation."174 The Preamble to the Constitution also favors the secular and liberal elements without referring to any definition of Islamic Sharia, considering it sufficient to state that the "definition of Islamic Sharia must follow rulings issued by the Supreme Constitutional Court," and giving the high court exclusive authority to "interpret constitutional articles in its rulings" as explained. ${ }^{175}$ The dreadful article 219 of the de facto 2012 Constitution stipulated that "[t]he principles of Islamic Sharia [by definition] include general evidence, foundational rules, rules of jurisprudence, and credible sources accepted in Sunni doctrines and by the larger community." 176

The religious clause, especially the Sharia Clause Guarantee, raised an inquiry regarding the standing of other Islamic doctrines and scholarships in Egyptian law, and gave an instrument for radical Islamists to restrict public freedoms and favor only one conservative, Sunni, jurisprudential linguistic interpretation over other doctrinal fiqh (opinions). ${ }^{177}$ The explicit term "principles" gave policymakers and legislators so much flexibility that they could almost apply the predominant positive laws - based on European and Napoleonic civil law-without any inconsistency with the "main principles" of Islamic (Sharia) law. Furthermore, the Preamble obviously detailed that "Egypt is now writing a Constitution that complements the construction of a modern democratic State, with a civilian government."179 Legal and constitutional experts pointed out several noteworthy and momentous enhancements over the

174. See 2014 Constitution, supra note 83, art. 2.

175. See 2014 Constitution, supra note 83, pmbl.

176. See 2012 Constitution, supra note 77, art. 219 (alteration added); see also Kirkpatrick, supra note 6.

177. See Arafa, supra note 164, at 182-3.

178. See Arafa, supra note 164, at 182-3.

179. See Essam El-din, supra note 165; see also Waleed Abdul Rahman, Egypt: Constitution Committee Reaches Agreement on Preamble, Civil State, AsHraQ AL-AwSAT (Nov. 29, 2013), http://www.aawsat.net/2013/11/article55323978/print/, archived at http://perma.cc/FRP8-JN9Q ("The members had voted in favor of drafting the constitution's preamble to state that 'Egypt is a democratic State with a civil system of rule.' The Salafist Al-Nour Party had pushed for the removal of the term 'civil' from the preamble, while also calling for the addition of a definition of the 'principles of Islamic Sharie'a law."'); see also Rana Muhammad Taha, Constitution's Preamble Preliminarily Passes, DAILY News, Nov. 29, 2013, http:/www.dailynewsegypt.com/2013/11/29/constitutions-preamble-preliminarilypasses/, archived at http://perma.cc/R4D-YEX7. 
abrogated 2012 Constitution. The most notable are the inclusive provisions on human, women's, minorities', and children's rights in the light of Egypt's obligation to stand by international human rights agreements ratified by its government. Additionally, privileges such as a criminal defendant's right to silence and the right to be free from discrimination, which is protected by a commission to fight discrimination, are granted ${ }^{180}$

The new 2014 Constitution refers to the religious minorities' legal status and states that "The principles of Christian and Jewish Sharia of Egyptian Christians and Jews are the main source of legislations that regulate their respective personal status, religious affairs, and selection of spiritual leaders." ${ }^{181}$ This provision represents a sort of guarantee to religious minorities such as Coptic Christians and Jews, but it still fails to mention the personal status of members of other religious assemblies and non-religious persons. ${ }^{182}$ In the same vein, article 47 refers to freedom of belief as "absolute" rather than "protected" as in the old draft. ${ }^{183}$ Both charters leave freedom to practice religion subject to the State's laws, which have traditionally offered scant protection against religious discrimination. ${ }^{184}$ "The freedom of practicing religious rituals and establishing worship places for the followers of Abrahamic religions is a right regulated by Law." 185 It should be noted that Islam grants absolute freedom for all religions, citing the Prophet Mohammad who said "[w]e are not entitled to open the hearts of others to know what their beliefs are," and "[n]o compulsion [should be] in religion," which means that the new constitutional structure must give all national citizens the right to practice devotion and exercise religion in an absolute, and common, sense. ${ }^{186}$

Furthermore, the new constitutional document includes a transitional article aimed at lifting all obstacles to building churches in Egypt by obliging the upcoming Parliament to issue a law regulating the building and

180. See generally Kareem Fahim \& Mayy El-Sheikh, In Egypt Charter, New Rights, But No Great Change, THE N.Y. Times, Dec. 1, 2013, http://www.nytimes.com/2013/12/02/world/middleeast/in-egypt-charter-new-rights-but-nogreat-change.html?_r=0, archived at http://perma.cc/5KZ6-35T9.

181. 2014 Constitution, supra note 83 , art. 3 .

182. See Arafa, supra note 164 , at 183.

183. 2014 Constitution, supra note 83 , art. 47.

184. In this respect, the ten-member technical constitutional committee drafted this provision to be read as: "Freedom of belief is guaranteed. The State guarantees freedom of religious practice, and facilitates the building of places of worship for the Abrahamic traditions, as regulated by law." See Gamal Essam El-Din, 2013 Amended Draft of Egyptian Constitution Passed to President, Ahramonline, Aug. 20, 2013, http://english.ahram.org.eg/News/79525.aspx, archived at http://perma.cc/MC92-AP98.

185. 2014 Constitution, supra note 83, art. 64.

186. See An Endless Debate Over Religion's Role, The Economist, Oct. 6, 2012, archived at http://perma.cc/FSY8-PX78 (alterations added). 
restoration of houses of worship, especially churches. ${ }^{187}$ Under the umbrella of a liberal — and not radical Islamic - constitution, all Egyptians, particularly Coptic Orthodox, must be permitted to build their own places of worship without restrictions, lamenting the flood of church torching across Egypt since the ouster of the former Islamist President. ${ }^{188}$ Moreover,

All citizens shall have the right to form political parties by notification as regulated by Law. No political activity may be practiced and no political parties may be formed on the basis of religion or discrimination based on sex, or origin, or on sectarian basis or geographic location. No activity that is hostile to democratic principles, secretive, or of military or quasi-military nature may be practiced.

Political parties may not be dissolved except by virtue of a court judgment. $^{189}$

Thus, the new Constitutional Charter prohibits and bans-in clear wording-political parties based on religion, and possibly, or at least theoretically, Islamist political parties based on religion-which could impact some parties formed after the January 25 Uprising. ${ }^{190}$ In other words, this textual provision outlaws the creation and the establishment of political parties based on religious, racial, sectarian or geographical basis, launching secretive or private parties and parties with a military or semimilitary nature, and excludes instituting parties that are "hostile to

187. 2014 Constitution, supra note 83, art. 235 (highlighting constructing and renovating churches). This Article deterred representatives and general sects councils of Egypt's three churches (the Coptic, Anglican, and Catholic) from withdrawing in objection at the demands of the representative of the ultraconservative Islamist on the role of Sharie' a, interpretation, and implementation in this document: "After this constitution goes into effect, the coming House of Representatives in its first session must issue a law aimed at regulating the construction and restoration of churches in a way that ensures and guaranteeing that Christians perform their religious rites freely." Id.

188. See generally Gamal Essam El-Din, Egypt's New Constitution to Guarantee Absolute Religious Freedom: Salmawy, Ahramonline (Oct. 28, 2013), http://english.ahram.org.eg/NewsContent/1/0/84992/Egypt/Egypts-new-constitution-toguarantee-absolute-reli.aspx, archived at http://perma.cc/P3UL-PMBB.

189. 2014 Constitution, supra note 83, art. 74 (regarding freedom to form political parties), cf. 2012 Constitution, supra note 77, art. 6 ("No political party shall be formed that discriminates on the basis of gender, origin or religion.").

190. Mariam Rizk and Osman El-Sharnoubi, Egypt's Constitution 2013 vs. 2012: A Comparison, AhrAmONLINE (Dec. 12, 2013), http://english.ahram.org.eg/News/88644.aspx. "Highlighting the extensive modifications which have produced the new charter. Alterations encompass the role of religion in legislation, the authority of the country's military, the system of governance, as well as the rights and freedoms of Egyptian citizens." Id. 
democratic principles."191

On the other hand, regarding enactment of legislation based on religious statutes or rules, the new amendments to the 2012 de facto Constitution omit any reference to the role of religious institutions with respect to enactments of legislation. ${ }^{192}$ Generally and legally speaking, in comparison to the 2012 de facto Charter, references to Islamic law (or Sharia) were reduced as the country's most imperative and prestigious religious foundation is no longer to have a say in legislation. ${ }^{193}$ Currently, the body in charge of deciding on legal matters of faith and religion is not a religious institution, but judicial, as it is now the Supreme Constitutional Court. ${ }^{194}$ Under the Islamist Constitution, it has been stipulated that:

Al-Azhar is an encompassing independent Islamic institution, with exclusive autonomy over its own affairs, responsible for preaching Islam, theology and the Arabic language in Egypt and the world. Al-Azhar Scholars are to be consulted in matters pertaining to Islamic law. The post of Al-Azhar Grand Sheikh is independent and cannot be dismissed. The method of appointing the Grand Sheikh from among members of the Senior Scholars is to be determined by law. The State shall ensure sufficient funds for Al-Azhar to achieve its objectives. ${ }^{195}$

Under this provision, members of the clerics from Al-Azhar, Egypt's most prominent Islamic institution, are "to be consulted on any matters related to Sharia," implicitly giving them oversight in legislation. Additionally, this wording gives Islamist religious jurists and intellectuals a role in reviewing statutes and regulations, as this opened the door for this credible Islamic association to be more corrupted. ${ }^{196}$ Also under this

191. See 2014 Constitution, supra note 83, at art. 74; see also Sarah El-Masry, Egypt's New Constitution: A Comparative Overview, Egypt Daily News, Dec. 8, 2013, http://www.dailynewsegypt.com/2013/12/08/egypts-new-constitution-a-comparativeoverview/.

192. See generally Markus Symank, 247 Articles for Egypt's Future, DW (Dec. 2, 2013), http://www.dw.de/247-articles-for-egypts-future/a-17266292.

193. Id.

194. Id.; see also Nassif Hitti, Challenges Await Egypt's New Constitution, AL-Monitor (Oct. 4, 2013), http://www.almonitor.com/pulse/tr/contents/articles/opinion/2013/10/constitution-egypt-challengessolutions-amendments.html.

195. See 2012 Constitution, supra note 77, at art. 4 .

196. In practice, this noteworthy religious agency has been proven to be effective and well-organized in undertaking its task and their role, however, regardless of the efficiency of this establishment, it will suffer from weaknesses in terms of their freedom of non-complete political independence; therefore, one of the foremost shortcomings of the governmental 
article: Parliament's members may submit controversial laws with religious context for "advisory opinions" or "consultancy;" these laws are "nonbinding," but Islamists still in power might use that "non-binding" result to build sustenance for religious legislation. ${ }^{197}$

Under the 2014 Constitution,

Al-Azhar is an independent Islamic scientific institution, with exclusive competence over its own affairs. It is the main reference for religious sciences and Islamic affairs. It is responsible for calling to Islam, as well as, disseminating religious sciences and the Arabic language in Egypt and all over the world. The State shall provide sufficient financial allocations thereto so that it can achieve its purposes. AlAzhar's Grand Sheikh is independent and may not be dismissed. The Law shall regulate the method of appointing the Grand Sheikh from amongst the members of Council of Senior Scholars. ${ }^{198}$

The new article protects al-Azhar's scholars and senior jurists from political interference by improving their independence and ensuring that no political intervention takes place in their decisions, as has been shown in several occurrences. ${ }^{199}$ Additionally, the neutrality this agency maintains adds to its credibility, impartiality, and should be preserved. ${ }^{200}$ Finally, for Egyptians of many diverse of stripes, "al-Azhar represents the true and best face of Islam as it is understood and practiced in Egypt." ${ }^{, 201}$ Al-Azhar's purpose is still modest [moderate] and not to govern the religious apparatus, only to adjust and promote its reasonable interpretation of Islamic law and Islam via training imams (leaders and jurists) who preach in remote villages and communities to, in part, overcome the influence of other extreme

institutions is their subordination to the executive branch. See Arafa, supra note 164, at 36.

197. Id.

198. See 2014 Constitution, supra note 83, art. 7.

199. See Dina Ezzat, New Constitution Fails to Delimit State and Islam: El-Houdaiby, Aharamonline, Dec. 15, 2013, http://english.ahram.org.eg/NewsContent/1/64/89040/Egypt/Politics-/Interview-Newconstitution-fails-to-delimit-state-.aspx, archived at http://perma.cc/T7RL-9PR5.

200. See generally Clark Lombardi and Nathan J. Brown, Islam in Egypt's New Constitution (University of Washington School of Law, Working Paper, 2012), available at http://papers.ssrn.com/sol3/papers.cfm?abstract_id=2258252. "The principles of the Islamic Sharia include its 'adillaa(h) al-kulliyaa(h), qawa'id usuliaa(h) and qawa'id fiqhiyyaa(h) and the sources considered by the Sunni madhhabs.' Scholars associated with the four Sunni schools wrote texts in a variety of genres. One set of texts explored questions of how to derive law from scripture (usul al-fiqh)." Id.

201. See generally Ahmad Morsy and Nathan J. Brown, Egypt's Al-Azhar Steps Forward, CARnegie Endowment For International Peace (Nov. 7, 2013), http://carnegieendowment.org/2013/11/07/egypt-s-al-azhar-stepsforward/gt0b?reloadFlag=1, archived at $\mathrm{http}: / /$ perma.cc/3BZX-2ARS. 
visions of Islam. ${ }^{202}$ Some distinguished improvements regarding the place of religious institutions in Egyptian public life have been realized ${ }^{203}$ The present moment is one of remarkable prospect for Al-Azhar as the foundation appears to be on the border of attaining more self-sufficiency, autonomy, and impact than it has had in the recent past. ${ }^{204}$

\section{EGYPT'S FUTURE DEMOCRACY: IS IT REAL OR FAKE? CONCLUSION AND POLICY RECOMMENDATIONS}

When Former Presidents Mubarak and Morsi were exiled from power in what became one of the crucial moments of the Arab Spring, an energetic public debate supervened about the character of the Egyptian society under the Constitution. For Egyptian citizens, after two remarkable uprisings, the new constitutional document had to guarantee the privileges of democracy and civil rights to all societal groups involved. In this phase of Egypt's Arab Spring to define the limitations of the Egyptian idea of democracy, the military would, in principle, not be involved in the political scene. However, when the values and principles of the State are at risk, the military could intervene-limited to setting things on the "right track" based on its historical and national responsibility. The intense and deep episode of Egyptian politics in the last few years devastated any presence of a genuine, smooth, and frank democratic transition. The preliminary social sensation surrounding Mubarak's overthrow gave the impression that Egypt was going toward an optimistic and bright democratic future. It was expected that with Mubarak's departure, most of Egypt's political impediments would vanish, as if the entire political, economic, social, and military configuration that empowered Mubarak to rule for such a long time-with an iron fist-was irrelevant. The legitimacy of the new Constitution will soon be put to a difficult test among the Egyptian general public.

The reality that the new Constitution replicates Egypt's contemporary overriding alliance is neither shocking nor novel. The structure of the preceding Islamist Constitution helped the coalition that ruled for a short time period, giving Morsi and the ruling Islamists an extensive base for inaugurating their theocratic plan. Still, the near future of Egypt's transition centers on whether the existing political coalition is more durable than the previous one. Based on the up-to-date economic statistics, the government will not be able to completely implement the Charter, and particularly within the prevailing economic status quo the recent data points to the substantial peril of such massive State spending. ${ }^{205}$ It could catalyze a

202. Id.

203. Id.

204. Id.

205. See generally The Heritage Foundation, 2014 Index of Economic Freedom: 
severe cash crisis that would expose food and fuel subsidies, harming huge sectors of the population and possibly lengthening support for antigovernment protests. ${ }^{206}$ If the government attempts to evade these results by not following the new Constitution, Egypt will continue to lack the legal rationalism that any constant and stable political system requires.

In theory, the Constitution should be a step forward in Egypt's twisting transition. Yet, it is certainly problematic to state that the Constitution alone will end Egypt's polarization and political and economic crisis, and bring genuine and effective stability. Without a doubt, the new Egyptian Constitution, as inadequate as it is, represents an enhancement over the Islamist-backed theocratic Constitution. Egypt will not be a "Jeffersonian" democracy, ${ }^{207}$ no matter who rules. Consequently, given the option between a liberal and secular régime dedicated to combating terrorism and standing by universal agreements, versus a dictatorial jihadist (religious fascism) rule that at best turned a blind eye to Islamist viciousness against Egyptian national citizens, the choice should be obvious.

Moreover, given the United States' interest in a secure and stable Egypt, moving towards operative civilian rule is arguably significant for part of the international community's security interests. Egypt needs a positive cultural attitude and the non-corruption of State bureaucracies, while being cautious in the upcoming years in selecting leaders who retain the dynamic for pure democratic values and self-motivated institutions. In Egypt, gradualism, more than anything, will be the political technique for allowing future generations to embrace democracy-building.

"Injustice anywhere is a threat to justice everywhere."

-Dr. Martin Luther King, Jr.

EGYPT (2014) (explaining percentage in rule of law, corruption, regulatory efficiency, and open markets policies), archived at http://perma.cc/U88M-UPRL.

206. See id; see also United NATiOns ECONOMic COMMission for Africa, The Economic Situation in Egypt in the ConteXt of Political Instability and a Risky TRANSITION (2013) (designing an economic recovery scenario), archived at http://perma.cc/6BPU-KHWP.

207. Jeffersonian Democracy, U.S. HIstory (last visited Sept. 22, 2014, archived at http://perma.cc/QN7X-A3TW). 